\title{
Physical and chemical properties of deposited airborne particulates over the Arabian Red Sea coastal plain
}

\author{
Johann P. Engelbrecht ${ }^{1,2}$, Georgiy Stenchikov ${ }^{1}$, P. Jish Prakash ${ }^{1}$, Traci Lersch ${ }^{3}$, Anatolii Anisimov ${ }^{1}$, and \\ Illia Shevchenko ${ }^{1}$ \\ ${ }^{1}$ King Abdullah University of Science and Technology (KAUST), Physical Science and Engineering Division (PSE), \\ Thuwal, 23955-6900, Saudi Arabia \\ ${ }^{2}$ Desert Research Institute (DRI), Reno, Nevada 89512-1095, USA \\ ${ }^{3}$ RJ Lee Group Inc., Monroeville, Pennsylvania 15146, USA \\ Correspondence to: Johann P. Engelbrecht (johann@dri.edu)
}

Received: 12 March 2017 - Discussion started: 9 May 2017

Revised: 3 August 2017 - Accepted: 15 August 2017 - Published: 27 September 2017

\begin{abstract}
Mineral dust is the most abundant aerosol, having a profound impact on the global energy budget. This research continues our previous studies performed on surface soils in the Arabian Peninsula, focusing on the mineralogical, physical and chemical composition of dust deposits from the atmosphere at the Arabian Red Sea coast. For this purpose, aerosols deposited from the atmosphere are collected during 2015 at six sites on the campus of the King Abdullah University of Science and Technology (KAUST) situated on the Red Sea coastal plain of Saudi Arabia and subjected to the same chemical and mineralogical analysis we conducted on soil samples. Frisbee deposition samplers with foam inserts were used to collect dust and other deposits, for the period December 2014 to December 2015. The average deposition rate measured at KAUST for this period was $14 \mathrm{~g} \mathrm{~m}^{-2}$ per month, with lowest values in winter and increased deposition rates in August to October. The particle size distributions provide assessments of $<10$ and $<2.5 \mu \mathrm{m}$ dust deposition rates, and it is suggested that these represent proxies for $\mathrm{PM}_{10}$ (coarse) and $\mathrm{PM}_{2.5}$ (fine) particle size fractions in the dust deposits.

X-ray diffraction (XRD) analysis of a subset of samples confirms variable amounts of quartz, feldspars, micas, and halite, with lesser amounts of gypsum, calcite, dolomite, hematite, and amphibole. Freeze-dried samples were resuspended onto the Teflon ${ }^{\circledR}$ filters for elemental analysis by X-ray fluorescence (XRF), while splits from each sample were analyzed for water-soluble cations and anions by ion chromatography. The dust deposits along the Red Sea coast are considered to be a mixture of dust emissions from lo-
\end{abstract}

cal soils and soils imported from distal dust sources. Airborne mineral concentrations are greatest at or close to dust sources, compared to those through medium- and long-range transport. It is not possible to identify the exact origin of deposition samples from the mineralogical and chemical results alone. These aerosol data are the first of their kind from the Red Sea region. They will help assess their potential nutrient input into the Red Sea, as well the impact on human health, industry, and solar panel efficiency. These data will also support dust modeling in this important dust belt source area by better quantifying dust mass balance and optical properties of airborne dust particles.

\section{Introduction}

Dust emission and deposition modeling and measurements are required for the assessment of the dust mass budget. Both emission and deposition are under-constrained in atmospheric dust models, leading to large uncertainties (Bergametti and Forêt, 2014; Schulz et al., 2012). To improve simulations, the above authors and others suggested the establishment of dust deposition networks in the vicinity of and away from dust source regions, operating throughout the year. In this paper we are presenting results from a network of dust deposition samplers located on the campus of the King Abdullah University of Science and Technology (KAUST) along the Red Sea coast of Saudi Arabia. This is an important dust source region (Ginoux et al., 2012; Prospero et al., 
2002), the effect of which extends thousands of kilometers downwind. To better characterize optical, microphysical, and health effects of dust aerosols we conducted detailed chemical, mineralogical and particle size analysis of deposition samples collected from the air.

\subsection{Importance of mineral dust}

Mineral dust is the most abundant atmospheric aerosol, primarily from suspended soils in arid and semi-arid regions on Earth (Buseck et al., 2000; Washington and Todd, 2005; Goudie, 2006; Muhs et al., 2014), including deserts of the Arabian Peninsula (Edgell, 2006). Dust aerosols profoundly affect climate (Haywood and Boucher, 2000; Hsu et al., 2004; Kumar et al., 2014), cloud properties (Twomey et al., 1984; Wang et al., 2010; Huang et al., 2006), visibility (Kavouras et al., 2009; Moosmüller et al., 2005), air quality (Hagen and Woodruff, 1973), atmospheric chemistry and mineralogy (Sokolik and Toon, 1999; Kandler et al., 2007), biogeochemical cycles in the ocean and over land (Jickells et al., 2005; Mahowald, 2009), human health (Bennett et al., 2006; Bennion et al., 2007; De Longueville et al., 2010; Menéndez et al., 2017), and agriculture (Fryrear, 1981; Nihlen and Lund, 1995).

A further important implication of dust emission/deposition processes is associated with the harvesting of the solar renewable energy in the desert areas. Dust deposits on solar panels are known to have a severe detrimental effect on the efficiency of photovoltaic systems (Goossens and Van Kerschaever, 1999; Hamou et al., 2014; Mejia et al., 2014; Rao et al., 2014; Sulaiman et al., 2014; Ilse et al., 2016), with its adverse effects depending on mineral composition and atmospheric conditions (Supplement B).

\subsection{Importance of dust mineralogy}

The importance of dust mineralogy has long been recognized (Engelbrecht et al., 2016), but only recently has the explicit transport of different mineralogical species been implemented in climate models (Perlwitz et al., 2015a, b; Scanza et al., 2015)

The mineralogy and chemical composition of dust generated from the Red Sea coastal region remains uncertain. The Red Sea coastal plain is a narrow highly heterogeneous piedmont area, and existing soil databases do not have the spatial resolution to represent it adequately (Nickovic et al., 2012).

The specific objective of the present study is to examine mineralogical, chemical and morphological information of deposition samples collected on the KAUST campus. This will help to better quantify the ecological impacts, health effects, damage to property, and optical effects of dust blown across this area (Engelbrecht et al., 2009a, b; Weese and Abraham, 2009). Knowledge of the mineralogy of the dust deposits will provide information on refractive indices, which can be used to calculate dust optical properties, pro- viding input into radiative transfer models, and to assess the impact of dust events on the Red Sea and adjacent coastal plain.

\subsection{Previous dust studies in the region}

This research complements our dust studies performed in the Arabian Peninsula (Engelbrecht et al., 2009a; Kalenderski et al., 2013; Jish Prakash et al., 2015, 2016) and globally (Engelbrecht et al., 2016).

The Arabian Peninsula is one of Earth's major sources of atmospheric dust, contributing as much as $11.8 \%$ (22$\left.500 \mathrm{Mta}^{-1}\right)$ of the total $\left(1877-4000 \mathrm{Mta}^{-1}\right)$ global dust emissions (Tanaka and Chiba, 2006). The Red Sea, being enveloped by the Arabian and African deserts, is strongly impacted by windborne mineral dust. Along with profound influence on the surface energy budget over land and the Red Sea (Kalenderski et al., 2013; Osipov et al., 2015; Brindley et al., 2015), dust is an important source of nutrients, more so for the oligotrophic northern Red Sea waters (Acosta et al., 2013). From preliminary assessments it is estimated that five to six major dust storms per year impact the Red Sea region, depositing about $6 \mathrm{Mt}$ of mineral dust into the Red Sea (Jish Prakash et al., 2015). Simulations and satellite observations suggest that the coastal dust contribution to the total deposition flux into the Red Sea could be substantial, even during fair weather conditions (Jiang et al., 2009; Anisimov et al., 2017). Therefore, the correct representation of the regional dust balance over the Red Sea coastal plain is especially important. Here we specifically focus on the dust deposition in this area, which helps to constrain the dust mass balance, as well as the dust mineralogy and chemical composition. Dust sources impacting on the Arabian Red Sea coastal region were shown to vary by season, coming from local haboobs and low-level jets, delivered from the Tokar Delta of Sudan in summer (Kalenderski and Stenchikov, 2016), and transported from the west coast of the Arabian Peninsula (Kalenderski et al., 2013).

Minerals previously identified in continental soils from Middle East dust-generating regions include quartz, feldspars, calcite, dolomite, micas, chlorite, kaolinite, illite, smectite, palygorskite, mixed-layer clays, vermiculite, iron oxides, gypsum, hornblende and halite (Engelbrecht et al., 2009b, 2016; Goudie, 2006; Jish Prakash et al., 2016; Pye, 1987; Scheuvens and Kandler, 2014). It could be expected that similar mineral assemblages would occur in variable proportions in the dust deposition samples collected in the region.

\section{Meteorology and climate}

With the exception of the area around Jazan in the south, which is impacted by the Indian Ocean monsoon, the Red Sea coastal region has a desert climate characterized by ex- 

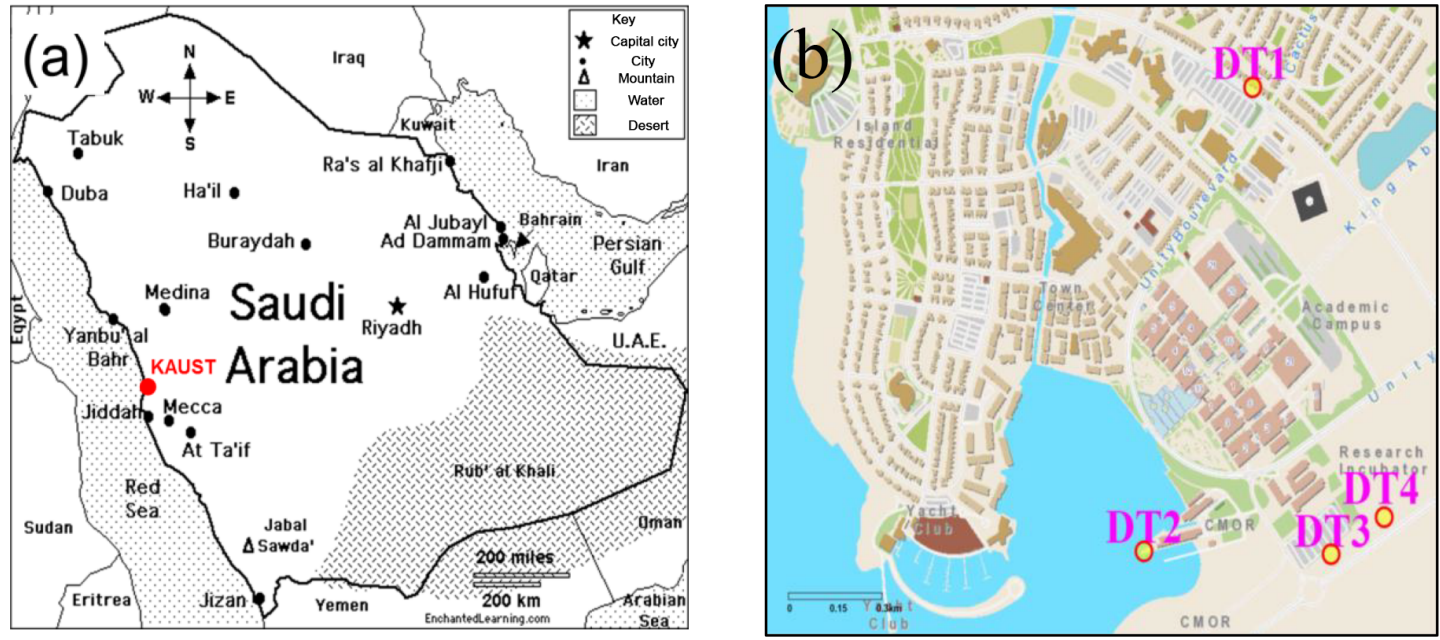

Figure 1. Position of (a) the King Abdullah University of Science and Technology (KAUST) campus on the Arabian Peninsula (red marker), north of the coastal city of Jeddah, and (b) the Frisbee deposition sites (DT1-DT4) on the KAUST campus.

treme heat. Temperatures measured at the KAUST campus reach $43{ }^{\circ} \mathrm{C}$ during the summer days, with a drop in nighttime temperatures on average of more than $10^{\circ} \mathrm{C}$. Although the extreme temperatures here are moderated by the proximity of the Red Sea, summer humidity is often $85 \%$ or higher during periods of the northwesterly shamal winds. Rainfall diminishes from an annual average of $133 \mathrm{~mm}$ at Jazan in the south to $56 \mathrm{~mm}$ at Jeddah, and $24 \mathrm{~mm}$ at Tabuk in the north (http://worldweather.wmo.int/en/city.html?cityId=699).

Vegetation is sparse, being restricted to semi-desert shrubs, and acacia trees along the ephemeral rivers (wadis), providing forage for small herds of goats, sheep, and dromedary camels.

During infrequent but severe rainstorms, run-off from the escarpment along wadis produces flash floods in lowland areas. With such events, fine silt and clay deposits are formed on the coastal plain, which are transformed into dust sources during dry and windy periods of the year. The resultant dust is transported and deposited along the coastal plain itself and adjacent Red Sea by prevailing northwesterly to southwesterly winds, with moderate breezes (wind speed $>5.5 \mathrm{~m} \mathrm{~s}^{-1}$ ) at the coast (http://www.windfinder.com/ weather-maps/report/saudiarabia\#6/22.999/34.980).

\section{Objectives}

This study is meant to complement the recently published papers by our research group that characterize the effect of dust storms (Jish Prakash et al., 2015; Kalenderski et al., 2013), evaluate radiative effect of dust (Osipov et al., 2015), and analyze soils from the Red Sea coastal plain (Jish Prakash et al., 2016) and dust emissions in the same region (Anisimov et al., 2017). Mineralogical, physical and chemical results are presented of deposition samples collected largely during 2015 at six sites on the campus of KAUST, located approximately $80 \mathrm{~km}$ north of Jeddah, along the central part of the Red Sea coastal plain of Saudi Arabia (Fig. 1).

\section{Regional dust sources}

The coastal plains of the Arabian Peninsula along the Red Sea and Persian Gulf are among the most populated areas in this region, hosting several major industrial and residential centers. Airborne dust profoundly affects human activities, marine and land ecosystems, climate, air quality, and human health. Satellite observations suggest that the narrow Red Sea coastal plain is an important dust source, augmented by fine sediment accumulations, scattered vegetation, and variable terrain. Airborne dust carries the mineralogical and chemical signature of a parent soil (Jish Prakash et al., 2016). The purpose of a previous study on 13 soil samples from the Arabian Red Sea coastal area (Jish Prakash et al., 2016) was to better characterize their mineralogical, chemical, and physical properties, which in turn improve assessment of dust being deposited in the Red Sea and on land, affecting environmental systems and urban centers. It was found that the Red Sea coastal soils contain major components of quartz and feldspar, as well as lesser but variable amounts of amphibole, pyroxene, carbonate, clays, and micas, with traces of gypsum, halite, chlorite, epidote and oxides. The mineral assemblages in the soil samples were ascribed to the variety of igneous and metamorphic provenance rocks of the Arabian Shield forming the escarpment to the east of the coastal plain.

\section{Sampling and analysis}

Anisimov et al. (2017) estimated that the eastern Red Sea coastal plain emits about 5-6 Mt of dust annually. Due to its 
(a)
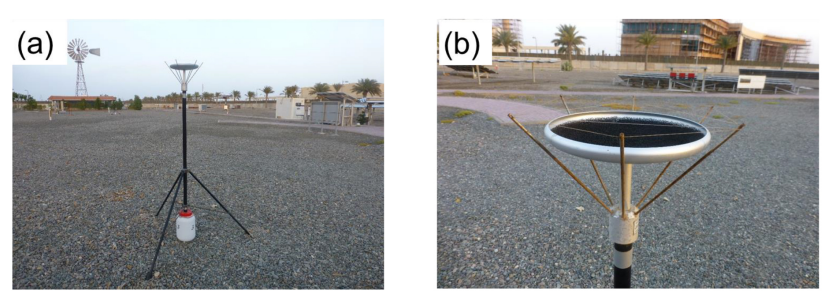

Figure 2. Inverted Frisbee-type deposition sampler (a) on tripod and white plastic drainage bottle. (b) View showing the foam insert in the collection dish to help retain the deposited dust particles, as well as the spikes with nylon thread to prevent birds from readily perching on the dish.

close proximity, a significant portion of this dust is likely to be deposited into the Red Sea, which could be comparable in amount to the estimated annual deposition rate from remote sources during major dust events (Jish Prakash et al., 2015). Therefore, we expect that the total dust deposition into the Red Sea is on the order of $10 \mathrm{Mt} \mathrm{a}^{-1}$, but this estimate still needs to be confirmed.

In the past few decades, wind tunnel and field tests have been performed on different designs of deposition samplers and sand traps to compare their efficiencies. The samplers and traps included marble dust collectors (MDCOs), inverted Frisbees, and glass surfaces (Goossens and Rajot, 2008; Sow et al., 2006; Goossens et al., 2000; Goossens and Offer, 2000). Most of the experiments performed in wind tunnels failed to completely mimic the field conditions, which resulted in an underestimation of the dust deposition, more so for the $<10 \mu \mathrm{m}$ size fraction (Sow et al., 2006). Based on the field evaluations by Vallack (1995) and suggestions by Vallack and Shillito (1998) the decision was taken to deploy inverted Frisbee samplers with foam inserts.

At each sampling site the particulate deposits were collected into a $227 \mathrm{~mm}$ diameter inverted Frisbee dust deposit sampler, each with a polyester foam insert and bird strike preventers (Hall et al., 1993; Vallack and Chadwick, 1992, 1993; Vallack and Shillito, 1998) (Fig. 2). The purpose of the foam insert is to enhance the particulate collection capacity of the dust gauge (Vallack and Shillito, 1998) by better collecting and retaining wet (from fog, dew, rain) and dry as well as fine and coarse particles, under stable meteorological conditions, during severe dust events, northwesterly shamal, and daily coastal winds.

For the period December 2014 to March 2015, four Frisbee samplers were located at the New Environmental Oasis (NEO) site, about $50 \mathrm{~m}$ apart. The gravimetric information from the four samplers were similar, with small variations amongst them ascribed to the impact from local construction activities. Due to the similarity of these gravimetric results, and to obtain a better representation of dust deposition onto the KAUST campus, two of the samplers (DT1 and DT2) were moved in March, the first (DT1) to a residential area and the other (DT2) to the quay adjacent to the Coastal \& Marine Resources Core Lab (CMOR) (Table 1). (Site metadata provided in Supplement A.)

The deposition samples were collected for intervals of a calendar month, starting in December 2014 and ending December 2015. At the end of each month, the samples are retrieved by flushing the dust deposit with distilled water from the foam insert and collection dish into the downpipe and plastic bottle. Both the insoluble particles and dissolved salts in the water suspension are retrieved in the laboratory by a freeze-drying (sublimation) procedure.

A total of 52 deposition samples were collected at the six sampling sites on the KAUST campus (Fig. 1b) over a period of 13 months, largely in 2015. Representative subsets of these samples were selected for electron microscopy (12 samples), XRD (27 samples) and chemical analysis (29 samples).

Freeze-dried sample splits were re-suspended in the laboratory onto Teflon ${ }^{\circledR}$ filters, for elemental analysis by XRF spectrometry using a miniaturized version of a dust entrainment facility (Engelbrecht et al., 2016) (http: //www.dri.edu/atmospheric-sciences/atms-laboratories/ 4185-dust-entrainment-and-characterization-facility). With this modified system the dust sample is drawn into a vertically mounted tubular dilution chamber, and the resuspended dust collected onto a $47 \mathrm{~mm}$ diameter Teflon ${ }^{\circledR}$ filter, for chemical analysis.

The samples re-suspended onto the Teflon ${ }^{\circledR}$ filters were chemically analyzed for elemental content by XRF, including for $\mathrm{Si}, \mathrm{Ti}, \mathrm{Al}, \mathrm{Fe}, \mathrm{Mn}, \mathrm{Ca}, \mathrm{K}, \mathrm{P}, \mathrm{V}, \mathrm{Cr}, \mathrm{Ni}, \mathrm{Cu}, \mathrm{Zn}, \mathrm{Rb}, \mathrm{Sr}$, $\mathrm{Y}, \mathrm{Zr}$, and $\mathrm{Pb}$ (US EPA, 1999). Splits of about $2 \mathrm{mg}$ from each freeze-dried sample were analyzed for water-soluble cations of sodium $\left(\mathrm{Na}^{+}\right)$, potassium $\left(\mathrm{K}^{+}\right)$, calcium $\left(\mathrm{Ca}^{2+}\right)$ and magnesium $\left(\mathrm{Mg}^{2+}\right)$, and anions of sulfate $\left(\mathrm{SO}_{4}^{2-}\right)$, chloride $\left(\mathrm{Cl}^{-}\right)$, phosphate $\left(\mathrm{PO}_{4}^{3-}\right)$, and nitrate $\left(\mathrm{NO}_{3}^{-}\right)$, using ion chromatography (IC) (Chow and Watson, 1999).

A subset of 27 samples from the total of 52 samples, representing all months of the year, was selected for X-ray diffraction (XRD) analysis. XRD is a non-destructive technique particularly suited to identify and characterize minerals such as quartz, feldspars, calcite, dolomite, clay minerals, and iron oxides, in fine soil and dust. Dust reactivity in seawater as well as optical properties depends on its mineralogy; e.g., carbonates and sulfates are generally more soluble in water than silicates such as feldspars, amphiboles, pyroxenes, or quartz. A Bruker D8 ${ }^{\circledR}$ X-ray powder diffraction system was used to analyze the mineral content of the dust deposition samples. The diffractometer was operated at $40 \mathrm{kV}$ and $40 \mathrm{~mA}$, with $\mathrm{Cu} \mathrm{K} \alpha$ radiation, scanning over a range of 4$50^{\circ} 2 \theta$. The Bruker Topas ${ }^{\circledR}$ software and relative intensity ratios (RIRs) were applied for semi-quantitative XRD analyses of the dust deposition samples (Rietveld, 1969; Chung, 1974; Esteve et al., 1997; Caquineau et al., 1997; Sturges et al., 1989). 
Table 1. Locality of deposition samplers at six sites on the campus of KAUST.

\begin{tabular}{|c|c|c|c|c|c|c|}
\hline & Site & Latitude & Longitude & $\begin{array}{l}\text { Elev. } \\
\text { ma.s.l. }\end{array}$ & Start & End \\
\hline \multirow{2}{*}{ DT1 } & NEO 1 & $22^{\circ} 18^{\prime} 16.12^{\prime \prime} \mathrm{N}$ & $39^{\circ} 6^{\prime} 28.46^{\prime \prime} \mathrm{E}$ & 1 & December 2014 & March 2015 \\
\hline & Res G3705 & $22^{\circ} 18^{\prime} 59.06^{\prime \prime} \mathrm{N}$ & $39^{\circ} 6^{\prime} 21.32^{\prime \prime} \mathrm{E}$ & 12 & April 2015 & December 2015 \\
\hline \multirow{2}{*}{ DT2 } & NEO 2 & $22^{\circ} 18^{\prime} 16.84^{\prime \prime} \mathrm{N}$ & $39^{\circ} 6^{\prime} 29.33^{\prime \prime} \mathrm{E}$ & 1 & December 2014 & March 2015 \\
\hline & CMOR & $22^{\circ} 18^{\prime} 16.60^{\prime \prime} \mathrm{N}$ & $39^{\circ} 6^{\prime} 7.91^{\prime \prime} \mathrm{E}$ & 1 & April 2015 & December 2015 \\
\hline DT3 & NEO 3 & $22^{\circ} 18^{\prime} 17.31^{\prime \prime} \mathrm{N}$ & $39^{\circ} 6^{\prime} 30.51^{\prime \prime} \mathrm{E}$ & 1 & December 2014 & December 2015 \\
\hline DT4 & NEO 4 & $22^{\circ} 18^{\prime} 18.10^{\prime \prime} \mathrm{N}$ & $39^{\circ} 6^{\prime} 31.52^{\prime \prime} \mathrm{E}$ & 1 & December 2014 & December 2015 \\
\hline
\end{tabular}

A likely bias in the results from applying the X-ray diffraction (XRD) technique, together with the RIR method is widely recognized, and therefore our methodology is considered to be semi-quantitative at best. Chung (1974) recognized that if the RIRs of all the crystalline phases in a mineral mixture are known, the sum of all the fractions should add to $100 \%$. However, XRD is effective at measuring crystalline phases such as quartz, calcite, and feldspars, and less so for partly crystalline and amorphous phases, including some layered silicates such as clays as well as many hydrous minerals. This could lead to an overestimation of the abundance of the crystalline mineral species in the dust, compared to partly crystalline and amorphous phases (Formenti et al., 2008; Kandler et al., 2009). Other discrepancies could occur from preferred orientation of layered silicates in the sample mounts. To minimize this effect, the dust samples were loaded into side-mount holders.

Electron microscopy provided information on the individual particle size and shape of micron-size particles, important for determining the optical parameters for modeling of dust (Moosmüller et al., 2012). The scanning electron microscope (SEM)-based individual particle analysis was performed on a subset of 12 deposition samples collected for each month of 2015. For each sample, a portion of the deposition sample was suspended in isopropanol and dispersed by sonication. The suspension was vacuum filtered onto a $0.2 \mu \mathrm{m}$ pore size polycarbonate substrate. A section of the substrate was mounted onto a metal SEM stub with colloidal graphite adhesive. The sample mounts were sputter-coated with carbon to dissipate the negative charge induced on the sample by the electron beam. The automated analysis was conducted on a Tescan MIRA $3{ }^{\circledR}$ field emission scanning electron microscope (FE-SEM) by rastering the electron beam over the sample while monitoring the resultant combined backscattered electron (BE) and secondary electron (SE) signals. Based on the grayscale levels, preset threshold values segmented the image into particles of interest and background. The system was configured to automatically measure the size and shape of anywhere from 5000 to 15000 particles per sample measuring $>0.2 \mu \mathrm{m}$ in average diameter. A digital image was acquired of each particle, for measurement, and stored for subsequent review. Size measurements were based on Feret diameters obtained from the projected area of each particle, by tracing their outer edges. This information was used to calculate the shape-dependent particle volumes. The particles were grouped into "bins" by their size. The field emission electron source allows for high magnifications and sharp secondary electron images (SEIs), as well as for the detailed study of particle size distributions.

Particle size distribution plots of 12 deposition samples collected monthly at the KAUST campus throughout the 2015 period are shown by volume in Appendix A and by number in Supplement C. The chemical abundance tables are in Appendix B. The mineralogical results from XRD are described under Sect. 5.5 and the normative mineralogy calculated from the chemistry, presented as histogram plots in Fig. 11.

\section{Results}

\subsection{Meteorology}

Northwesterly shamal winds prevailed during all 12 months of 2015 (Fig. 3). Four to five severe dust storms lasting 3 to 5 days each, contributed to hot humid conditions during the summer months. Weaker northeasterly winds were experienced in October and November of that year. Although the northeasterly winds were more frequent in November, they did not reach the maximum strength of the northwesterly winds.

The first 4 months in the second half of 2015 experienced the highest ambient temperatures (Table 2), with an average temperature of $35^{\circ} \mathrm{C}$ for August followed by $34^{\circ} \mathrm{C}$ for September, bracketed by $33^{\circ} \mathrm{C}$ for both July and October. The highest single temperature was $43^{\circ} \mathrm{C}$, recorded in October, with the coolest temperature of $17^{\circ} \mathrm{C}$ in January of that year. The range of temperatures was the greatest through fall, winter and spring, with large diurnal temperature fluctuations during these seasons. The humidity at KAUST is consistently high (Table 2 ), with averages varying from $57 \%$ for December and $61 \%$ for January to as high as $82 \%$ for August and $80 \%$ for September. Dew points were 


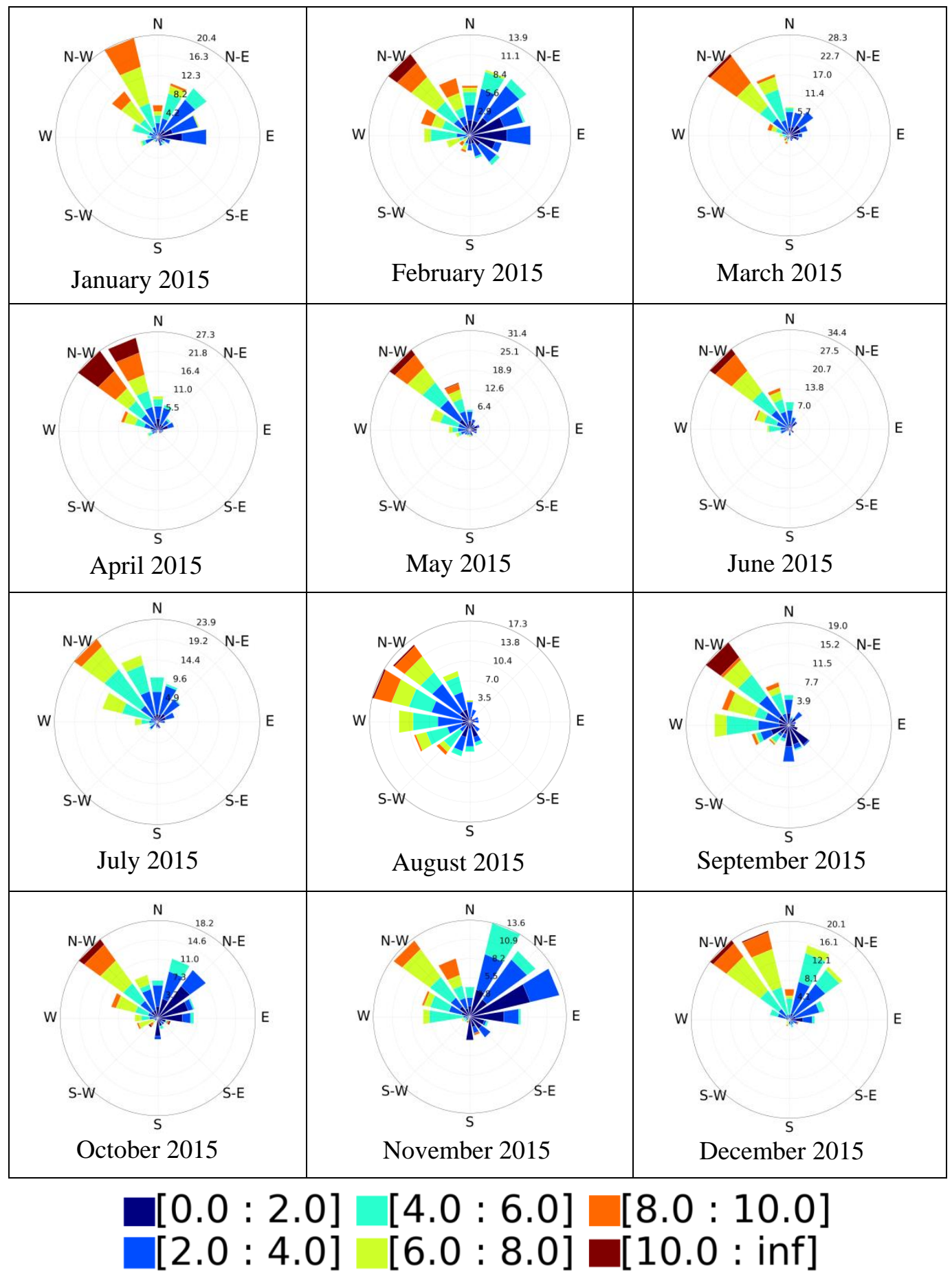

Figure 3. Wind $\left(\mathrm{m} \mathrm{s}^{-1}\right)$ roses for each month of 2015 .

calculated for each set of hourly measurements, applying the August-Roche-Magnus approximation (Alduchov and Eskridge, 1996; August, 1828; Magnus, 1844). The highest dew point temperatures were calculated in August $\left(31^{\circ} \mathrm{C}\right)$ and September $\left(30^{\circ} \mathrm{C}\right)$, while the month with the greatest frequency of humidity measurements (96) in excess of $90 \%$ was also recorded in August (Table 2, Fig. 4). The lowest monthly frequency (4) for humidity exceeding $90 \%$ was December. In 2015, there were only a few light rainfall events at KAUST, and as such not of much importance to our measurements. 
Table 2. Monthly averaged temperatures, humidity measurements, and calculated dew points at KAUST during 2015.

\begin{tabular}{|c|c|c|c|c|c|c|c|c|c|}
\hline \multirow{2}{*}{ Month } & \multicolumn{4}{|c|}{ Temperature } & \multicolumn{4}{|c|}{ Humidity } & \multirow{2}{*}{$\begin{array}{r}\text { Dew point } \\
\text { Avg. }{ }^{\circ} \mathrm{C}\end{array}$} \\
\hline & Avg. ${ }^{\circ} \mathrm{C}$ & Min. ${ }^{\circ} \mathrm{C}$ & $\operatorname{Max} .{ }^{\circ} \mathrm{C}$ & Range ${ }^{\circ} \mathrm{C}$ & Avg. $\%$ & Min. $\%$ & Max. \% & $\mathrm{N}>90 \%$ count & \\
\hline Jan & 25 & 17 & 33 & 16 & 61 & 10 & 99 & 27 & 17 \\
\hline Feb & 27 & 19 & 33 & 14 & 74 & 15 & 99 & 48 & 21 \\
\hline Mar & 28 & 23 & 36 & 14 & 76 & 29 & 99 & 32 & 23 \\
\hline Apr & 28 & 23 & 34 & 12 & 74 & 23 & 99 & 43 & 23 \\
\hline May & 32 & 29 & 37 & 9 & 77 & 21 & 99 & 65 & 27 \\
\hline Jun & 32 & 28 & 37 & 9 & 76 & 22 & 99 & 26 & 27 \\
\hline Jul & 33 & 29 & 38 & 9 & 75 & 26 & 99 & 55 & 28 \\
\hline Aug & 35 & 33 & 40 & 7 & 82 & 36 & 99 & 96 & 31 \\
\hline Sep & 34 & 30 & 38 & 8 & 80 & 26 & 99 & 63 & 30 \\
\hline Oct & 33 & 29 & 43 & 14 & 72 & 9 & 96 & 32 & 27 \\
\hline Nov & 30 & 25 & 35 & 10 & 69 & 25 & 99 & 19 & 23 \\
\hline Dec & 27 & 20 & 32 & 12 & 57 & 15 & 94 & 4 & 17 \\
\hline
\end{tabular}

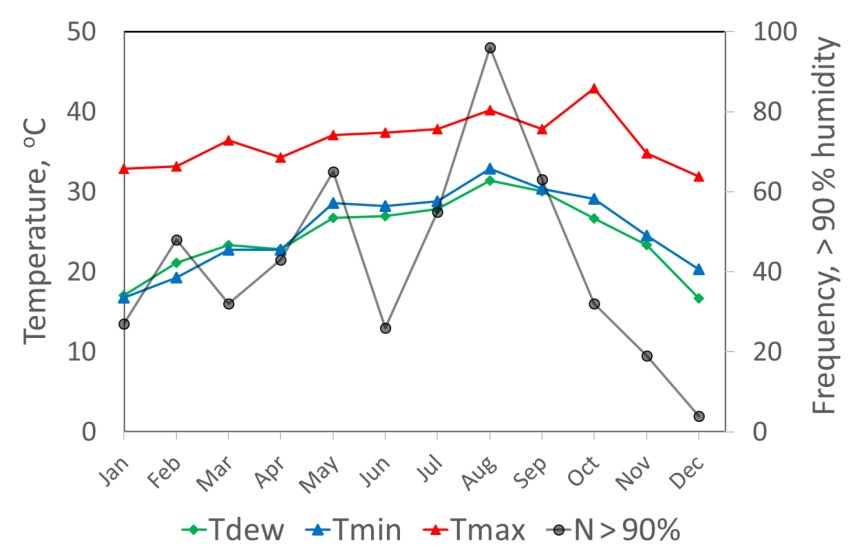

Figure 4. Monthly averaged minimum (blue, $\triangle$ ) and maximum (red, $\triangle$ ) ambient temperatures as well as dew point (green, $\diamond$ ) variations for KAUST during 2015. Also shown for each month is the frequency of hourly humidity measurements exceeding $90 \%$ (black, o ).

\subsection{Gravimetric analysis}

With a few exceptions, the monthly gravimetric measurements from the four samplers (DT1-DT4) are comparable (Fig. 5), changing similarly by month and season. The deposition rates were at their lowest for December 2014 (avg. $4 \mathrm{~g} \mathrm{~m}^{-2}$ ), increasing steadily for 4 months to a peak value for March 2015 (avg. $20 \mathrm{~g} \mathrm{~m}^{-2}$ ) before decreasing over the subsequent 4 months to a low for July (avg. $5 \mathrm{~g} \mathrm{~m}^{-2}$ ). The deposition rates increased sharply for August $\left(28 \mathrm{~g} \mathrm{~m}^{-2}\right)$, September $\left(23 \mathrm{~g} \mathrm{~m}^{-2}\right)$ and October $\left(28 \mathrm{~g} \mathrm{~m}^{-2}\right)$, before diminishing in November $\left(14 \mathrm{~g} \mathrm{~m}^{-2}\right)$ and December $\left(11 \mathrm{~g} \mathrm{~m}^{-2}\right)$. The NEO terrain is close to several building construction sites, about $400 \mathrm{~m}$ to the east and southeast of the installed deposition samplers, which periodically created substantial amounts of local airborne dust. This, together with the windy conditions, is held responsible for elevated dust concentra-

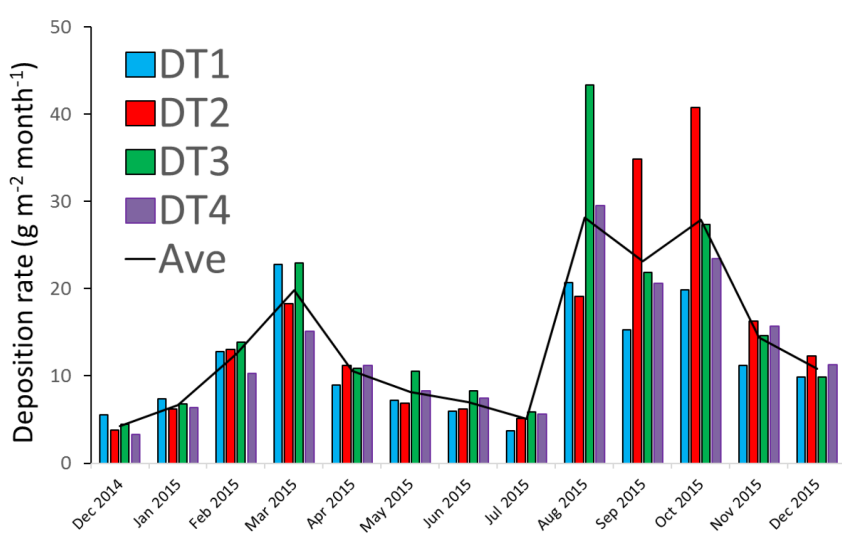

Figure 5. Monthly deposition rates $\left(\mathrm{g} \mathrm{m}^{-2}\right)$ from Frisbee samplers (DT1-DT4) at the KAUST campus. Also shown are the monthly averages for the four samplers.

tions measured at the two NEO sites (DT3, DT4). The higher deposition rate at DT3 for August, compared to DT4, is ascribed to the fact that the former sampler is about $100 \mathrm{~m}$ closer to construction material handling activities during that month. Wind-blown sea spray during stormy conditions was responsible for elevated deposition levels of sea salt at the CMOR (DT2) quay-side site, for the months of September and October 2015.

Source apportionment is considered to be a following step in the Red Sea dust research program. As an approximation of source contributions, the sampler with the lowest deposition rate can be considered to have negligible or contain the least amount of local dust and sea salt (Fig. 5). In the months of December 2014 and January, April, March, June, July, and December 2015, the deposition rates at the four sampling sites were similar and considered to have similar but negligible amounts of dust from local construction, roads, marine salt, or other particulates. In August, it is estimated that 


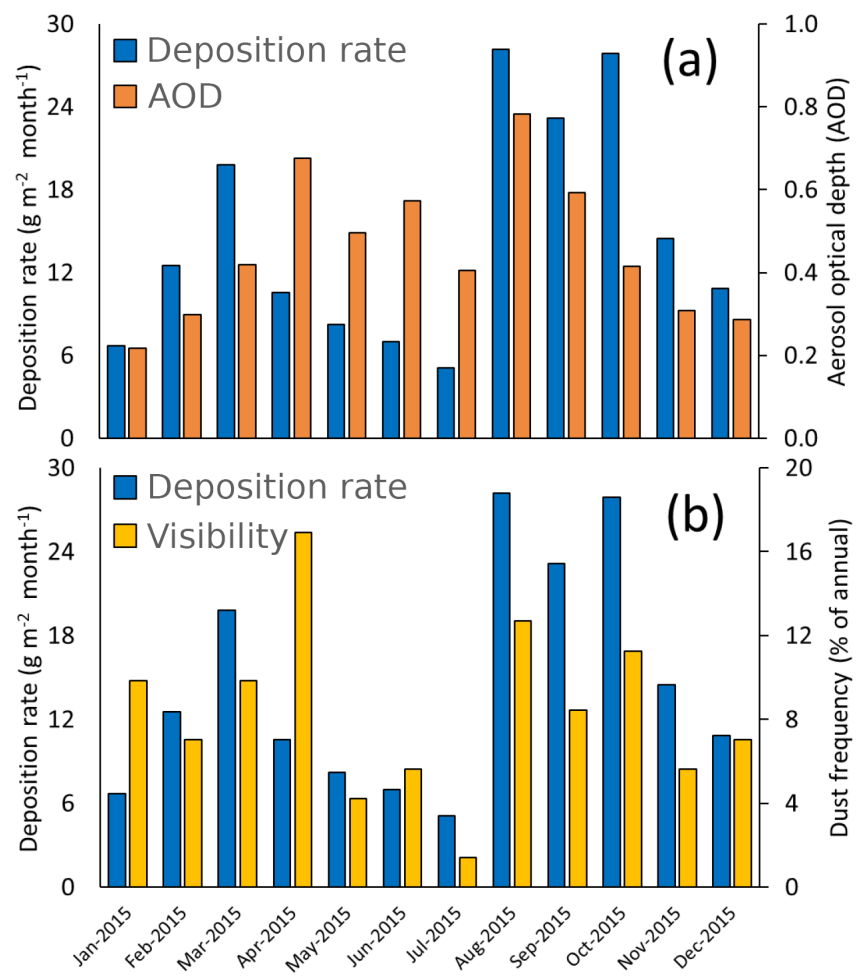

Figure 6. Average monthly deposition rates for all four samplers (DT1-DT4) on the KAUST campus, together with (a) monthly averaged AOD measurements from the KAUST AERONET site, and (b) monthly averaged visibility measurements collected from the Jeddah airport, for 2015 .

24-56 $\mathrm{g} \mathrm{m}^{-2}$ month $^{-1}(10-35 \%)$ of the dust captured at sites DT3 and DT4 was from local construction and motor traffic. Similarly, it is estimated that the deposition rates of sea salt at DT2 varied from $20-21 \mathrm{~g} \mathrm{~m}^{-2}$ month $^{-1}$ (51-56\%) over the months of September and October.

Bearing in mind that the dust deposition samplers, sampling procedures, and conditions and sampling periods were different to those of this study, some comparisons to similar studies in desert regions are listed in Table 3. The deposition rates from this study, both on average $\left(14 \mathrm{~g} \mathrm{~m}^{-2}\right.$ month $\left.{ }^{-1}\right)$ and in range (4-28 $\mathrm{g} \mathrm{m}^{-2}$ month $^{-1}$ ), were found to be similar to those previously recorded by Offer and Goossens (2001) in the Negev Desert, Israel (average $17 \mathrm{~g} \mathrm{~m}^{-2}$ month $^{-1}$, range $10-25 \mathrm{~g} \mathrm{~m}^{-2}$ month $^{-1}$ ), and western Niger (Goossens and Rajot, 2008) (average $13 \mathrm{~g} \mathrm{~m}^{-2}$ month $^{-1}$, range 6$21 \mathrm{~g} \mathrm{~m}^{-2}$ month $\left.^{-1}\right)$. A campaign in the Saudi Arabian capital of Riyadh (Modaihsh, 1997; Modaihsh and Mahjoub, 2013) during the dusty months of January to March showed average monthly deposition rates of $42 \mathrm{~g} \mathrm{~m}^{-2}$ and a range of 20$140 \mathrm{~g} \mathrm{~m}^{-2}$. The dust deposition measured in Kuwait on the other hand, varies substantially between sites due to the contribution from disturbed soils in lowlands during periods of northwesterly shamal winds.

\subsection{AERONET and visibility measurements}

The aerosol optical depth (AOD) is one of the best observed aerosol characteristics. It defines the aerosol radiative effect and reflects the abundance of aerosols in the atmosphere. A CIMEL robotic sun photometer is installed on the rooftop of the CMOR building on the campus of the KAUST and operated by our group since 2012, as a part of the NASA AERONET, providing aerosol optical depth (AOD) and aerosol-retrieved characteristics (https://aeronet. gsfc.nasa.gov/). Figure 6a compares the monthly averaged $\mathrm{AOD}$ at $500 \mathrm{~nm}$ with the dust deposition rate for 2015. In a general sense the AOD and the deposition rates show comparable trends, both with maxima in spring and larger maxima in fall. However, the AOD reaches a first maximum in April, being 1 month later than that of the deposition rate. Also, the larger second AOD maximum occurred in August while the maximum deposition rate is broadly distributed over a 3-month period, from August to October, with AOD in October being relatively low. The linear correlation coefficient between the monthly deposition rates and the monthly averaged AOD of 0.40 suggests a causal interrelationship between these two quantities. However, for a number of reasons it is relatively low. The photometer measures light attenuation by all aerosols along a column in the atmosphere, while deposition rate depends on dust at ground level only, the latter generally containing a relatively coarser dust fraction. The low-level dust particles are partly from local dust sources while the higher altitude dust could be transported from distal sources and chemically transformed, i.e., aged. As was pointed out by Yu et al. (2013) the differences between the deposition and AOD time series can in part be attributed to modifications of the natural dust aerosol by anthropogenic activities, including petrochemical and other large industries along the Red Sea coast, as well as by entrainment of construction and road dust. However, the substantial contamination of dust by anthropogenic species and sea salt is not likely in this area, as was suggested by both observational (Osipov et al., 2015; Brindley et al., 2015) and modeling studies (Kalenderski and Stenchikov, 2016). To further test whether the non-dust fine aerosols (or remotely transported fine dust) significantly contribute to the interrelation between AOD and deposition rates, we followed two additional approaches. We screened the AODs by low Ångström exponent value $(<0.3)$, suggested to correspond to dust (Ginoux et al., 2012), and considered the contribution to the total AOD from the spectral deconvolution algorithm (SDA) fine-mode aerosol product. Neither technique contributed to an increase of correlation coefficient. The discrepancy of high AOD, low deposition rate in summer (low Ångström exponent) and low AOD, high deposition rate in October still remained when AODs were screened. The fine-mode AOD remains almost constant throughout the year, and its contribution cannot explain the discrepancy. 
Table 3. Dust deposition measurements from the Middle East and other global dust regions.

\begin{tabular}{|c|c|c|c|c|c|}
\hline Study & Locality & Sampler type & Sampling period & $\begin{array}{r}\text { Average } \\
\text { deposition rate } \\
\left(\mathrm{g} \mathrm{m}^{-2} \mathrm{month}^{-1}\right)\end{array}$ & $\begin{array}{r}\text { Range } \\
\text { deposition rate } \\
\left(\mathrm{g} \mathrm{m}^{-2} \mathrm{month}^{-1}\right)\end{array}$ \\
\hline (a) This study (2017) & Saudi Arabia, KAUST & Frisbee with foam insert & Dec 2014-Dec 2015 & 14 & 4-28 \\
\hline (b) Modaihsh and Mahjoub (2013) & Saudi Arabia, Riyadh & Dish with marbles & Jan-Mar? & 42 & $20-140$ \\
\hline (c) Khalaf and Al-Hashash (1983) & Kuwait, NW gulf & Polyethelene cylinders with water & Apr 1979-Mar 1980 & 191 & $10-1003$ \\
\hline (d) Al-Awadhi (2005) & Kuwait, NE bay & PVC bucket with marbles & May 2002-Apr 2003 & 28 & $3-58$ \\
\hline (e) Al-Awadhi and AlShuaibi (2013) & Kuwait City & PVC bucket with marbles & Mar 2011-Feb 2012 & 53 & $2-320$ \\
\hline (f) Offer and Goossens (2001) & Israel, Negev & Marble collectors & $1988-1997$ & 17 & $10-25$ \\
\hline (g) Goossens and Rajot (2008) & Niger, Banizoumbou & Frisbee with marbles, original data & 8 periods in 2005 & 13 & $6-21$ \\
\hline (h) Smith and Twiss (1965) & USA, Kansas & Cylindrical rain gauge with screens & June 1963-June 1964 & 6 & $3-14$ \\
\hline
\end{tabular}
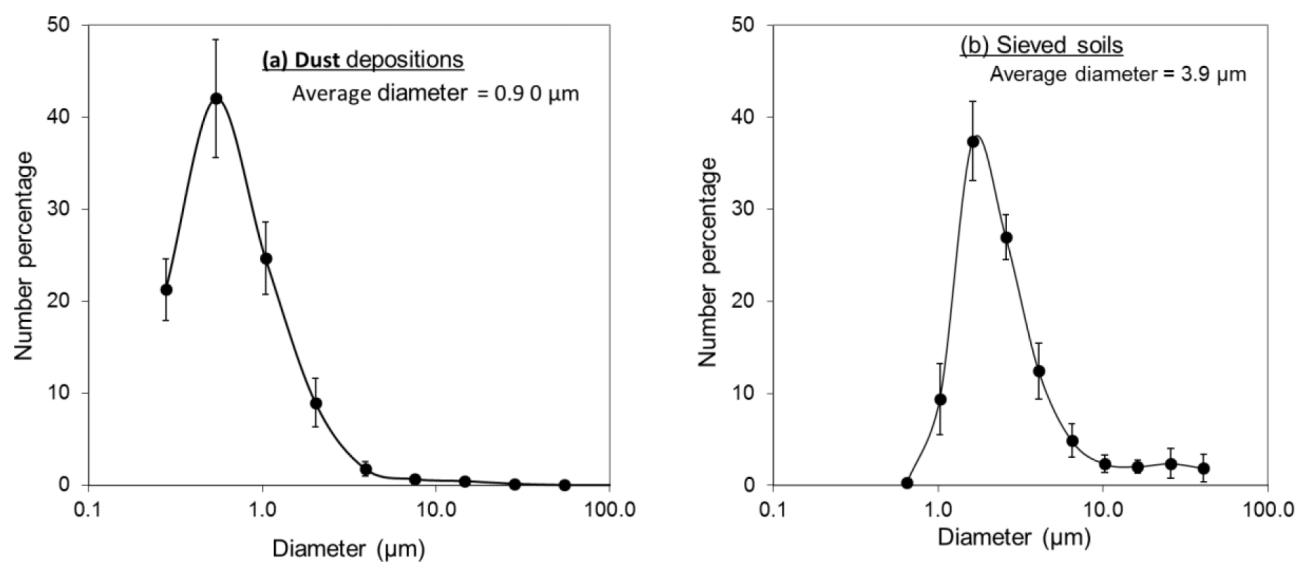

Figure 7. Average particle size distributions and standard deviations of (a) 12 deposition samples collected by Frisbee samplers on KAUST campus and of (b) $13<38 \mu \mathrm{m}$ sieved soil samples from a previous study (Jish Prakash et al., 2016), both measured by SEM.

Furthermore, a comparison between the deposition samples and the visibility is made with measurements taken in 2015 at the Jeddah airport meteorological station, approximately $70 \mathrm{~km}$ to the south of KAUST. Visibility is expressed as the frequency of dust events with reported weather codes 06-09 or 30-35, grouped as dusty or non-dusty days, for each month (Notaro et al., 2013; Anisimov et al., 2017), expressed as percentages. The bimodal monthly distributions seen with the deposition rates and AERONET monitoring are also mirrored by the visibility measurements collected at Jeddah (Fig. 6b). The linear correlation coefficient between the monthly deposition rates and monthly averaged visibility measurements is 0.48 , clearly suggesting a causal relationship between the two variables.

\subsection{Particle size distributions (PSDs)}

Dust deposition rates depend on the meteorological conditions, and dust properties such as particle size distribution, their vertical distribution, and abundance.

Summary plots of results from SEM-based individual particle analysis for each month of 2015, expressed by number are presented in Supplement $\mathrm{C}$ to this paper. From these particle size and shape measurements, equivalent shapedependent volumes for the particles were calculated, the summary plots of which are shown in Appendix A. The volume of each particle is calculated from the measured maximum and minimum diameters, and assuming a prolate spheroid. Also, assuming a similar average density of, for example, $2.65 \mathrm{~g} \mathrm{~cm}^{-3}$ for all minerals in the deposition samples results in similar volume and mass distributions patterns. This was confirmed by XRD measurements and the abundance of quartz $\left(2.65 \mathrm{~g} \mathrm{~cm}^{-3}\right)$, feldspar $\left(\sim 2.65 \mathrm{~g} \mathrm{~cm}^{-3}\right)$, micas $\left(\sim 2.83 \mathrm{~g} \mathrm{~cm}^{-3}\right)$, and clays $\left(\sim 2.7-2.8 \mathrm{~g} \mathrm{~cm}^{-3}\right)$ found in the deposition samples. The volume distributions were applied to assess the mass percentages and deposition rates of each size bin, e.g., the mass percentages and mass deposition rates of particles in bins less $<10 \mu \mathrm{m}$ in average diameter, and similarly less than $<2.5 \mu \mathrm{m}$ in average diameter, together with their uncertainties (Table 4). The contribution of particles $<10 \mu \mathrm{m}$ to the total measured mass varies between about 4 and $17 \%$ with an average of $8.6 \%$ for the 12 months. Particles less than $2.5 \mu \mathrm{m}$ range from about 0.6 to $4 \%$, with an average of $1.2 \%$ for the 12 -month period. From these percentages and the total deposition rates, average deposition rates of $1.2 \pm 0.7 \mathrm{~g} \mathrm{~m}^{-2}$ month $^{-1}$ for $<10 \mu \mathrm{m}$ and $0.1 \pm 0.1 \mathrm{~g} \mathrm{~m}^{-2}$ month $^{-1}$ for $<2.5 \mu \mathrm{m}$ are estimated.

The average size distribution of the 12 deposition samples (Fig. 7a) is compared to that of the 13 surface soils (Fig. 7b) from potential dust source regions along the Red Sea coastal 
Table 4. Monthly measured deposition rates and assessments of $<10$ and $<2.5 \mu$ m deposition rates from SEM-based particle size measurements.

\begin{tabular}{|c|c|c|c|c|c|c|}
\hline \multirow{3}{*}{ Sample no. } & \multirow{3}{*}{ Month (2015) } & \multicolumn{5}{|c|}{ Deposition rate } \\
\hline & & \multirow{2}{*}{$\begin{array}{r}\text { Total } \\
\mathrm{g} \mathrm{m}^{-2} \text { month }^{-1}\end{array}$} & \multicolumn{2}{|c|}{$<10 \mu \mathrm{m}$} & \multicolumn{2}{|c|}{$<2.5 \mu \mathrm{m}$} \\
\hline & & & $\%$ of total & $\mathrm{g} \mathrm{m}^{-2}$ month $^{-1}$ & $\%$ of total & $\mathrm{g} \mathrm{m}^{-2}$ month $^{-1}$ \\
\hline DT3.1_012015 & January & 7.34 & $16.5 \pm 4.3$ & $1.2 \pm 0.3$ & $4.0 \pm 1.6$ & $0.29 \pm 0.12$ \\
\hline DT3.1_022015 & February & 12.83 & $7.0 \pm 3.3$ & $0.9 \pm 0.4$ & $0.9 \pm 0.4$ & $0.12 \pm 0.05$ \\
\hline DT3.4_032015 & March & 15.11 & $12.0 \pm 5.8$ & $1.8 \pm 0.9$ & $1.6 \pm 0.6$ & $0.24 \pm 0.09$ \\
\hline DT3.4_042015 & April & 11.22 & $8.7 \pm 2.8$ & $1.0 \pm 0.3$ & $0.8 \pm 0.3$ & $0.09 \pm 0.03$ \\
\hline DT3.3_052015 & May & 10.51 & $7.3 \pm 2.1$ & $0.8 \pm 0.2$ & $0.8 \pm 0.3$ & $0.08 \pm 0.03$ \\
\hline DT3.3_062015 & June & 8.28 & $9.0 \pm 2.8$ & $0.7 \pm 0.2$ & $0.9 \pm 0.3$ & $0.07 \pm 0.02$ \\
\hline DT3.3_072015 & July & 5.86 & $9.7 \pm 6.3$ & $0.6 \pm 0.4$ & $1.1 \pm, 0.7$ & $0.06 \pm 0.04$ \\
\hline DT3.3_082015 & August & 43.39 & $6.4 \pm 3.3$ & $2.8 \pm 1.4$ & $0.6 \pm 0.4$ & $0.26 \pm 0.17$ \\
\hline DT3.3_092015 & September & 21.90 & $4.3 \pm 7.1$ & $0.9 \pm 1.6$ & $0.6 \pm 1.0$ & $0.13 \pm 0.22$ \\
\hline DT3.3_102015 & October & 27.39 & $9.2 \pm 7.3$ & $2.5 \pm 2.0$ & $0.8 \pm 0.6$ & $0.22 \pm 0.16$ \\
\hline DT3.3_112015 & November & 14.59 & $6.1 \pm 1.4$ & $0.9 \pm 0.2$ & $0.7 \pm 0.2$ & $0.10 \pm 0.03$ \\
\hline DT3.3_122015 & December & 9.91 & $7.3 \pm 2.5$ & $0.7 \pm 0.2$ & $1.1 \pm 0.2$ & $0.11 \pm 0.02$ \\
\hline
\end{tabular}

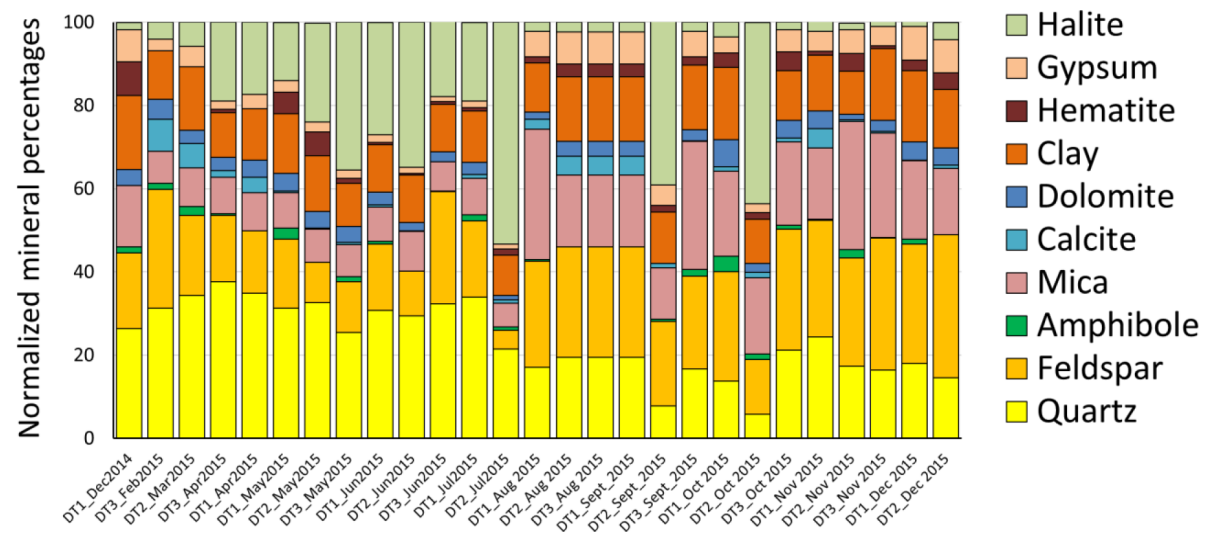

Figure 8. Semi-quantitative XRD mineral analyses of monthly Frisbee samples collected at the three sites DT1-DT3, for the period December 2014 to December 2015.

plain (Jish Prakash et al., 2016). The deposition samples with an average diameter of $0.9 \mu \mathrm{m}$ are much finer than the $3.9 \mu \mathrm{m}$ average diameter of the $<38 \mu \mathrm{m}$ sieved soils. In addition the Frisbee sampler is biased towards the sampling of the coarser particles, as previously documented (Bergametti and Forêt, 2014; Goossens, 2005).

\subsection{Mineral analysis by XRD}

XRD analysis of the 27 samples (Fig. 8) shows variable amounts of quartz (6-38\%, avg. $22 \%$ ) and feldspars (plagioclase, K-feldspar) (5-34\%, avg. $20 \%$ ), clays (10-18\%, avg. $13 \%)$, micas (6-31\%, avg. $13 \%)$, halite (1-53\%, avg. $7 \%)$ with lesser amounts of gypsum (1-8\%, avg. $4 \%)$, calcite $(0-$ $8 \%$, avg. $2 \%)$, dolomite (0-7\%, avg. $3 \%)$, hematite ( $0-8 \%$, avg. $3 \%$ ), and amphibole (and pyroxene) (0-4\%, avg. $1 \%$ ).

From the XRD, four broad mineral assemblages are distinguished: the first and major assemblage is comprised of feldspars, clays, and micas, as well as hematite and gypsum; the second group is of quartz, the third of halite, and the fourth of calcite.

There is an increase in the halite concentrations at sites DT1-DT3, from about $2 \%$ (DT1) in December 2014 to about $53 \%$ (DT2) in July 2015 (Fig. 8). From August onwards there is an abrupt decrease in halite content to less than $5 \%$, except for samples collected at the DT2 (CMOR, quay-side) site alongside the ocean. There was a simultaneous increase in the proportion of quartz to a maximum of $38 \%$ in April (DT3), decreasing to less than $25 \%$ at all sites after July 2015. The silicate mineral group decreased systematically from about $72 \%$ (DT1) in December 2014 to about $25 \%$ (DT2) in July. Except for two samples from the DT3 site collected in September and October 2015, the dominant minerals after July, 2015 included the silicate assemblage, with concentrations of up to $80 \%$. The variation in the proportions of the four mineral assemblages, especially the halite, 

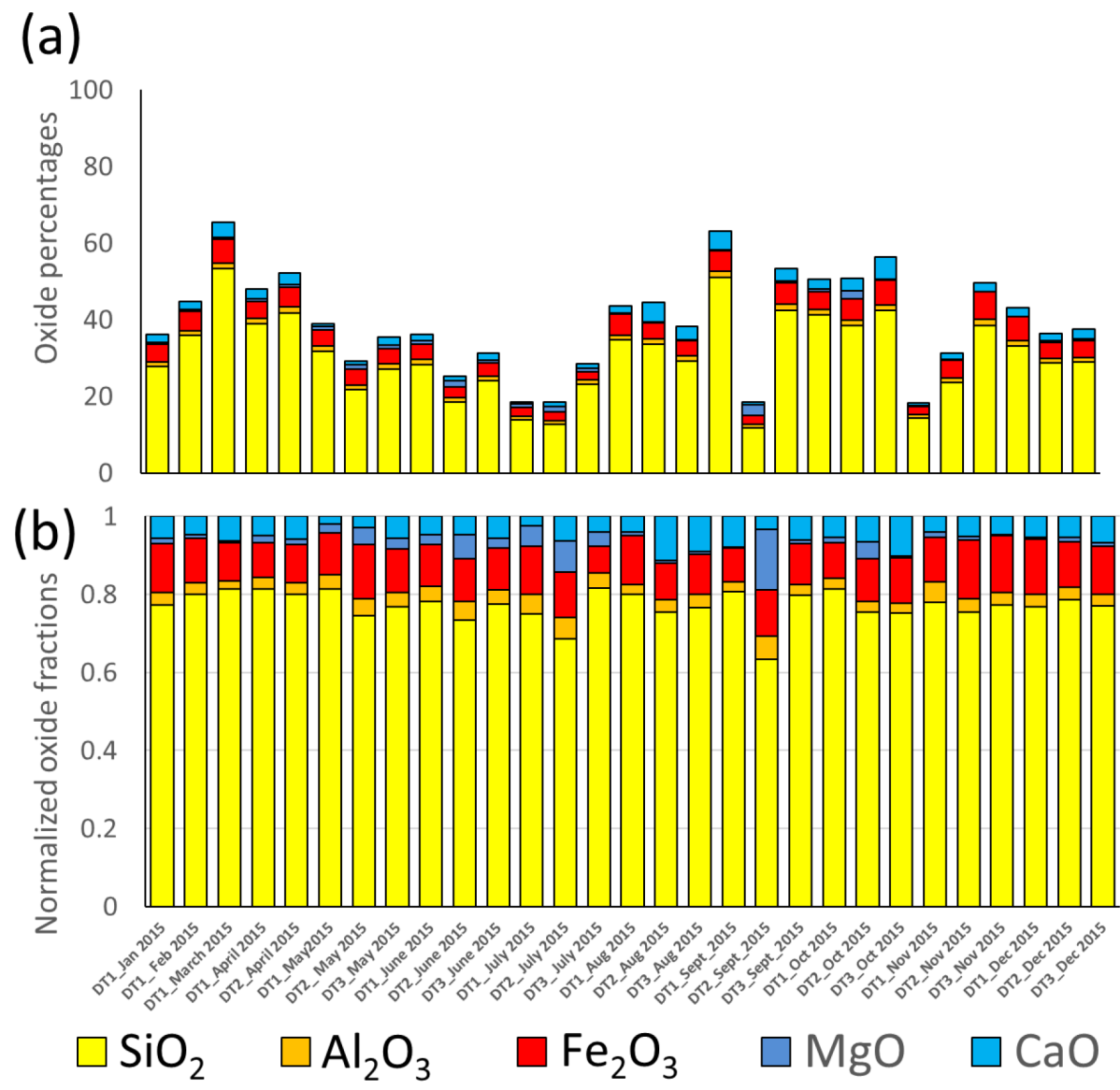

Figure 9. (a) Deposition sample elemental compositions, expressed as oxides and (b) fractions normalized to unity.

is ascribed to seasonal fluctuations in wind, humidity, and precipitation, as well as the proximity of the sea to the sampling sites.

SEM-based SEIs of individual dust particles show that the larger particles being composed of mineral aggregates and coatings on other mineral particles. Examples (Supplement D) include particles composed of coatings of clay minerals on quartz and feldspar; clusters of clay minerals, calcite, gypsum, and halite; and particles and clusters of iron oxides and clay minerals. Similar coatings and aggregates in re-suspended soil samples are reported by Engelbrecht et al. (2016).

\subsection{Chemistry (XRF and IC)}

As expected, the chemically analyzed deposition samples contain major amounts of $\mathrm{SiO}_{2}$ (Appendix A, Fig. 9a, b), varying between 12 and $53 \%$ (avg. $31 \%$ ) in the sample subset, occurring as quartz, and together with $\mathrm{Al}_{2} \mathrm{O}_{3}$ (avg. $4 \%$ ) and $\mathrm{CaO}$ (avg. $2.3 \%$ ) in plagioclase, and $\mathrm{K}_{2} \mathrm{O}$ (avg. $0.6 \%$ ) in potassium feldspars. $\mathrm{SiO}_{2}$, together with $\mathrm{Al}_{2} \mathrm{O}_{3}, \mathrm{Fe}_{2} \mathrm{O}_{3}$, $\mathrm{TiO}_{2}, \mathrm{MnO}, \mathrm{MgO}$, and some $\mathrm{K}_{2} \mathrm{O}$, is also contained in the clays, micas, and amphiboles, previously identified in these samples by optical microscopy and XRD. Lesser amounts of
$\mathrm{CaO}$ are contained in gypsum and calcite and, together with $\mathrm{MgO}$, in dolomite. The iron expressed here as $\mathrm{Fe}_{2} \mathrm{O}_{3}$ can be contained in hematite $\left(\mathrm{Fe}_{2} \mathrm{O}_{3}\right)$, goethite $\mathrm{FeO}(\mathrm{OH})$, or clay minerals such as illite, each with different solubility. It has been suggested that large fractions of iron in soils and dusts are contained as amorphous colloidal coatings on quartz and feldspars (Engelbrecht et al., 2016).

The water-soluble cations (Appendix A, Fig. 10a, b) account for $1-19 \%$ and the anions for $1-30 \%$ of the total mass, respectively. These account for variable amounts of halite (1-32\%), and gypsum (1-9\%), with lesser amounts of other chlorides and carbonates. Of importance as dustborne nutrients likely to be deposited in the Red Sea, are the low concentrations of both water-soluble $\mathrm{NO}_{3}^{-}$(avg. $0.8 \%$ ), and water-soluble $\mathrm{PO}_{4}^{3-}$ (avg. $0.2 \%$ ) compared to the total $\mathrm{P}_{2} \mathrm{O}_{5}$ (avg. $0.3 \%$ ) in the dust deposits. The phosphorus is contained in the largely insoluble mineral apatite (francolite), found in the sedimentary rocks underlying large parts of the Arabian Peninsula (Notholt et al., 2005).

The sum of chemical species, including elements expressed as oxides, as well as ion concentrations, varies from 35 to $78 \%$, with an average of $56 \%$ of the measured chemical mass. The shortfall from $100 \%$ is attributed in part to 

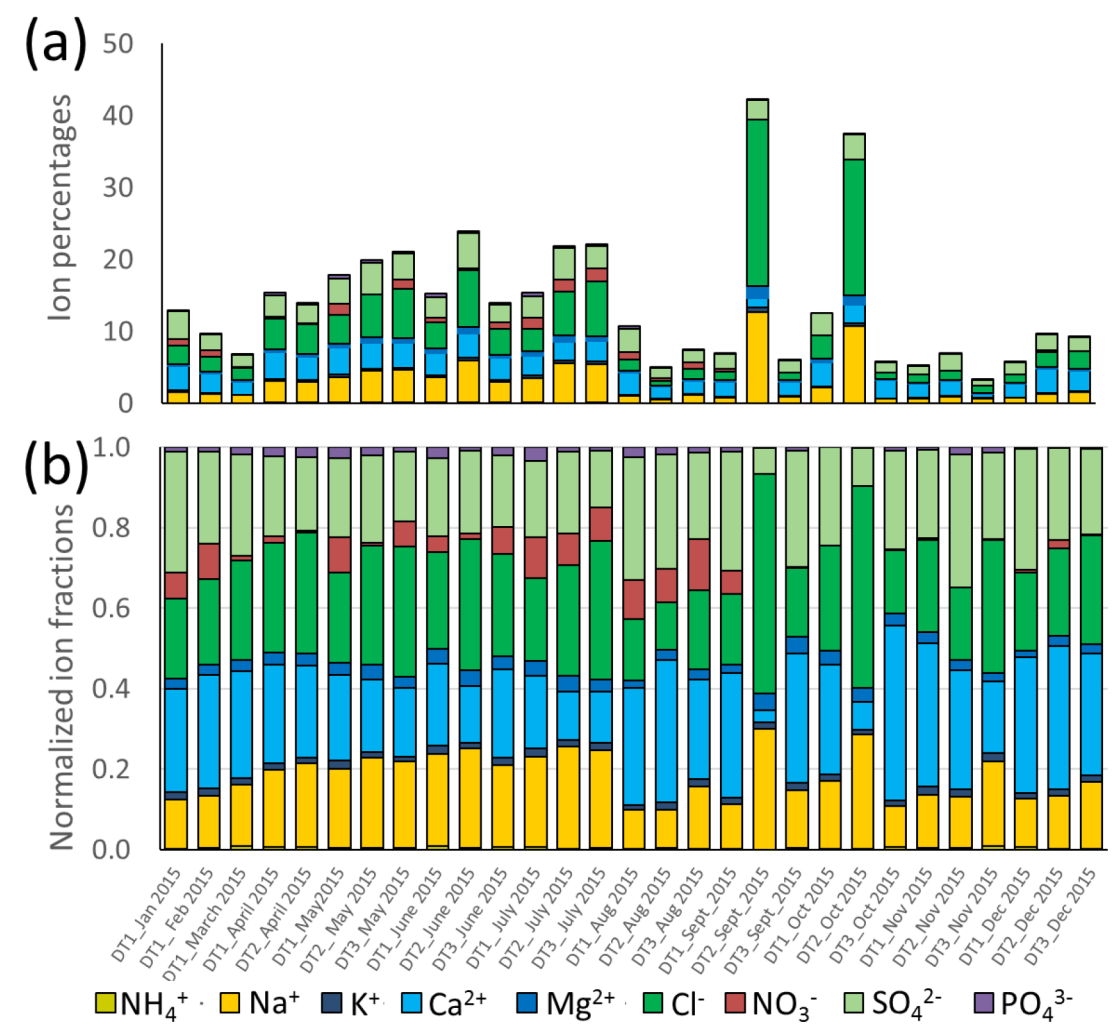

Figure 10. (a) Ion concentrations and (b) fractions totaled to unity.

components not analyzed for, including $\mathrm{H}_{2} \mathrm{O}, \mathrm{OH}$, carbon $\left(\mathrm{CO}_{3}^{2-}\right.$, organic carbon, elemental carbon), and artifacts of debris deposited onto the samplers.

The chemical abundances were recalculated as normative minerals (Fig. 11a, b), comparable in composition to those identified by XRD (Fig. 8) and optical microscopy. The relative normative mineral abundances (Fig. 11b) show variable amounts of quartz (avg. $52.4 \%$ ) feldspar (avg. $3.9 \%$ ), kaolinite $(2.6 \%)$, calcite $(8.8 \%)$ dolomite $(0.2 \%)$, and hematite $(8.0 \%)$, as well as the evaporate minerals gypsum $(12.1 \%)$, halite $(12.1 \%)$, sylvite $(0.2 \%)$, and bischofite $(0.2 \%)$. There is also, as shown by XRD, an increase in halite content from about $7.8 \%$ in January to about $25.9 \%$ in July, followed by a sharp drop to about $4.6 \%$ in August, with greater abundances at the CMOR quayside site in September (51.0\%) and October $(31.6 \%)$, ascribed to sea spray from stormy conditions during those 2 months.

Elemental mass ratios of the Frisbee deposition samples are compared to the $<38 \mu \mathrm{m}$ sieved soil samples from the Arabian Red Sea coastal plain (Jish Prakash et al., 2016), and total suspended particulate (TSP) samples collected at other sites in the Middle East (Engelbrecht et al., 2009a) are compared in Table 5. The average $\mathrm{Si} / \mathrm{Al}$ ratio of 6.86 of the Frisbee deposition samplers is intermediate to the 13.60 of the Arabian Red Sea coastal soils and the approximately unity of the Middle East samples. The $\mathrm{Fe} / \mathrm{Al}$ ratios of the sample sets show similar relationships as the $\mathrm{Si}$ / $\mathrm{Al}$ ratios, being intermediate to the Red Sea coastal soils and four of the five other Middle East countries, excluding the UAE, to which it is similar. The difference is ascribed to the greater abundance of the minerals such as quartz in the coarser sieved soil samples, and less thereof in the finer TSP fractions. The $\mathrm{Ca} / \mathrm{Al}$ ratio of 2.17 is similar to those of TSP samples from samples of Qatar (2.07) and the UAE (2.16), ascribed to the regional carbonate-bearing soils in all three countries. The average $\mathrm{Ti} / \mathrm{Al}, \mathrm{Mg} / \mathrm{Al}$, and $\mathrm{K} / \mathrm{Al}$ ratios of the Frisbee deposition samples are substantially lower than those of the Red Sea coastal soils, which may be related to mineralogical differences in the dust source regions. Differences can also be ascribed to larger percentages of Al-bearing minerals such as clays in the deposition samples from this study.

\section{Summary and conclusions}

This study provides new mineralogical, physical, and chemical information on deposition samples collected at the KAUST campus during 2015, as well as an assessment of the seasonal variability of the regional dust deposition rates onto the Saudi Arabian coastal plain.

Inverted Frisbee samplers with foam inserts are found to be robust, easy to use, and provided comparable results for the collection of wet and dry deposits. Once a month the sam- 


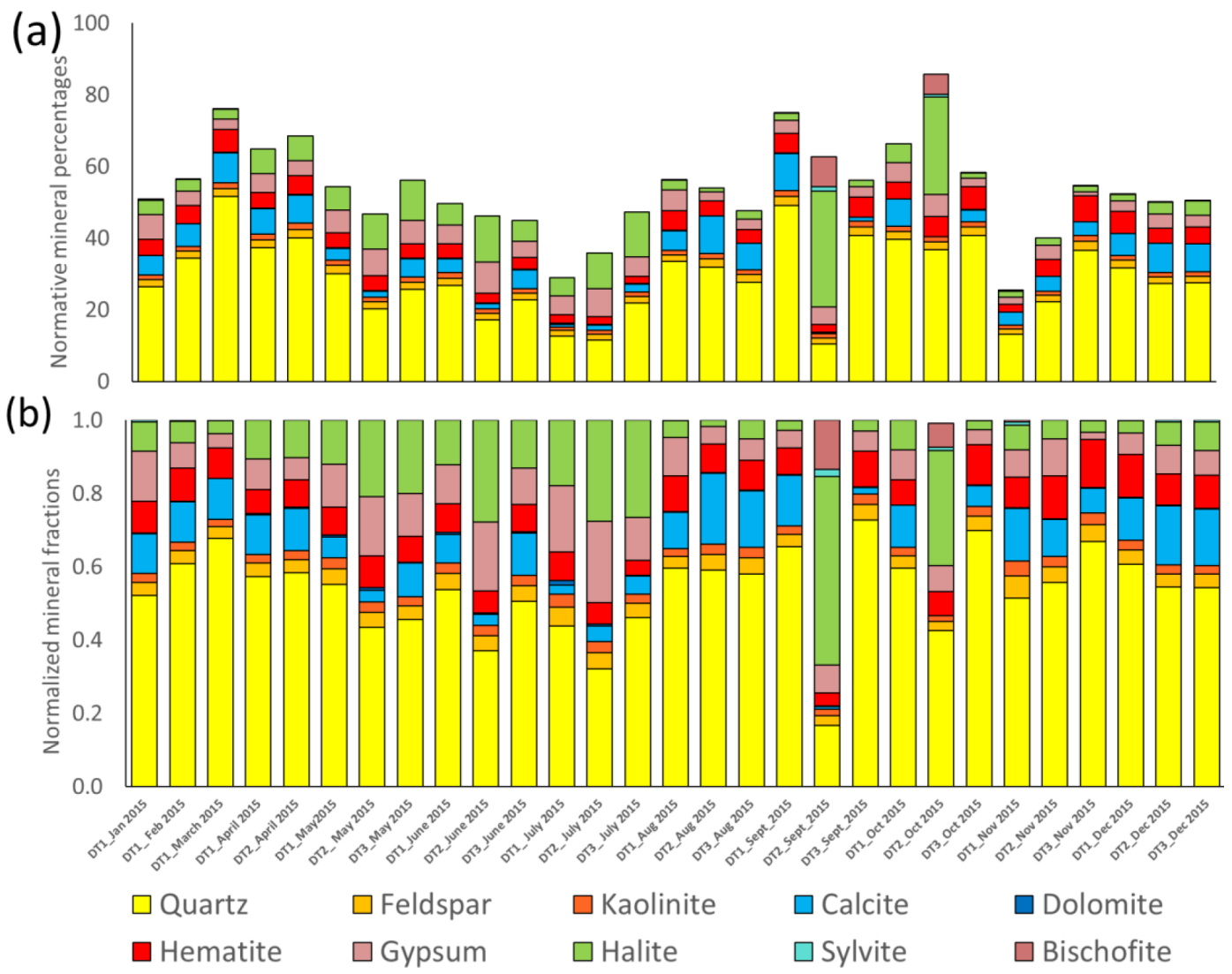

Figure 11. (a) Chemical abundances combined as normative minerals, and (b) those normalized to $100 \%$.

Table 5. Elemental mass ratios for the deposition samples from this study, compared to those of soils from the Red Sea coastal plain (Jish Prakash et al., 2016) and TSP samples from other countries of the Middle East (Engelbrecht et al., 2009a). The TSP filter samples were collected by low-volume aerosol samplers without size selective inlets, for $24 \mathrm{~h}$ sampling periods.

\begin{tabular}{llrrrrrr}
\hline & & $\mathrm{Si} / \mathrm{Al}$ & $\mathrm{Ti} / \mathrm{Al}$ & $\mathrm{Fe} / \mathrm{Al}$ & $\mathrm{Mg} / \mathrm{Al}$ & $\mathrm{Ca} / \mathrm{Al}$ & $\mathrm{K} / \mathrm{Al}$ \\
\hline Frisbee & Deposition & 6.86 & 0.14 & 1.47 & 0.11 & 2.17 & 0.34 \\
Saudi soils & Sieved $<38 \mu \mathrm{m}$ & 13.60 & 0.44 & 2.52 & 0.65 & 0.36 & 0.43 \\
Djibouti & TSP & 0.92 & 2.19 & 1.12 & 0.88 & 0.74 & 1.14 \\
Afghanistan & TSP & 1.05 & 1.25 & 1.00 & 0.94 & 0.69 & 1.96 \\
Qatar & TSP & 1.02 & 0.24 & 0.98 & 1.40 & 2.07 & 0.93 \\
UAE & TSP & 1.29 & 0.28 & 1.52 & 2.85 & 2.16 & 1.02 \\
Iraq & TSP & 1.03 & 0.72 & 0.99 & 1.11 & 1.31 & 1.04 \\
Kuwait & TSP & 1.07 & 0.65 & 0.99 & 1.25 & 1.23 & 0.94 \\
\hline
\end{tabular}

ples are retrieved by flushing the deposits into plastic flasks followed by freeze drying of the slurry and recovery of all suspended particles and dissolved salts. The average deposition rate at KAUST for 2015 was $14 \mathrm{~g} \mathrm{~m}^{-2}$, with $4 \mathrm{~g} \mathrm{~m}^{-2}$ in December, $20 \mathrm{~g} \mathrm{~m}^{-2}$ in March, $5 \mathrm{~g} \mathrm{~m}^{-2}$ in July, and $28 \mathrm{~g} \mathrm{~m}^{-2}$ in September and October, decreasing to $11 \mathrm{~g} \mathrm{~m}^{-2}$ the following December. The changes are ascribed to seasonally variable meteorological conditions, including high humidity prevailing along the Arabian Red Sea coastal plain during the late summer and autumn months. The particle size dis- tributions provide an assessment of $<10$ and $<2.5 \mu \mathrm{m}$ dust deposition rates, the former varying $0.6-2.8 \mathrm{~g} \mathrm{~m}^{-2}$ and the latter $0.06-0.29 \mathrm{~g} \mathrm{~m}^{-2}$ per month. We suggest these deposition rates as proxies for those of $\mathrm{PM}_{10}$ (coarse) and $\mathrm{PM}_{2.5}$ (fine), respectively.

Chemical analysis, confirmed by XRD, points to a consistent silicate mineral fractions for the deposition samples, at all sampling sites for the entire sampling period. The $\mathrm{Si} / \mathrm{Al}, \mathrm{Fe} / \mathrm{Al}$, and $\mathrm{Ca} / \mathrm{Al}$ ratios of the deposition samples fall within the range of the soil samples previously collected 
along the Arabian Red Sea coastal plain as well as the TSP size fractions collected at several sites in the Middle East. It is proposed that the dust deposits along the Red Sea coast are a mixture of dust emissions from local soils and soils imported from distal dust sources. Airborne mineral concentrations are greatest at or close to dust sources, compared to dusts, due to medium and long-range transport.

For 2015, there are marked similarities between monthly distribution patterns of the deposition samples and AOD measured at KAUST, as well as visibility measurements from Jeddah airport, $70 \mathrm{~km}$ to the south. This shows that both the AOD and visibility measurements mirror fluctuations in dust deposition, although it may not be justified to calculate quantitative interrelationships without further research.

Except for the variable halite fractions and local construction dust, there are minor variations in the mineralogical content of the dust samples collected on the KAUST campus. To better model the dust being deposited in the Red Sea and coastal plain, the sampling campaign should be extended to sites beyond the KAUST campus. Such a sampling site was recently set up on an island off the coast from KAUST. Inclusion of particle size with mineralogical and chemical measurements provides more effective data for the modeling community.
The deposition samplers collect all particle sizes; however, bin aerosol models usually consider only $\mathrm{PM}_{10}$. The estimated $\mathrm{PM}_{10}$ deposition rates are lower than the total particulate deposition rates we observed. However, the size distribution of deposited particles shown in Fig. 7a and Appendix A could be used to assess the contribution of $\mathrm{PM}_{10}$ in deposited mass and reconcile models with observations. Alternatively, the calculated particle size range in the models can be potentially be extended to cover TSP. However, this could be computationally extensive.

As an approximation of source contributions, the sampler with the lowest deposition rate can be considered to have negligible or the least amount of local dust or sea salt (Fig. 5). In the months of December 2014, January, April, March, June, July, and December 2015, the deposition rates at the four sites were similar and considered to have no or negligible amounts of dust from local construction, campus roads, marine salt, or other particulates.

Data availability. The gravimetric, mineralogical, and chemical data from this study are available upon request from Georgiy Stenchikov (georgiy.stenchikov@kaust.edu.sa). 


\section{Appendix A}
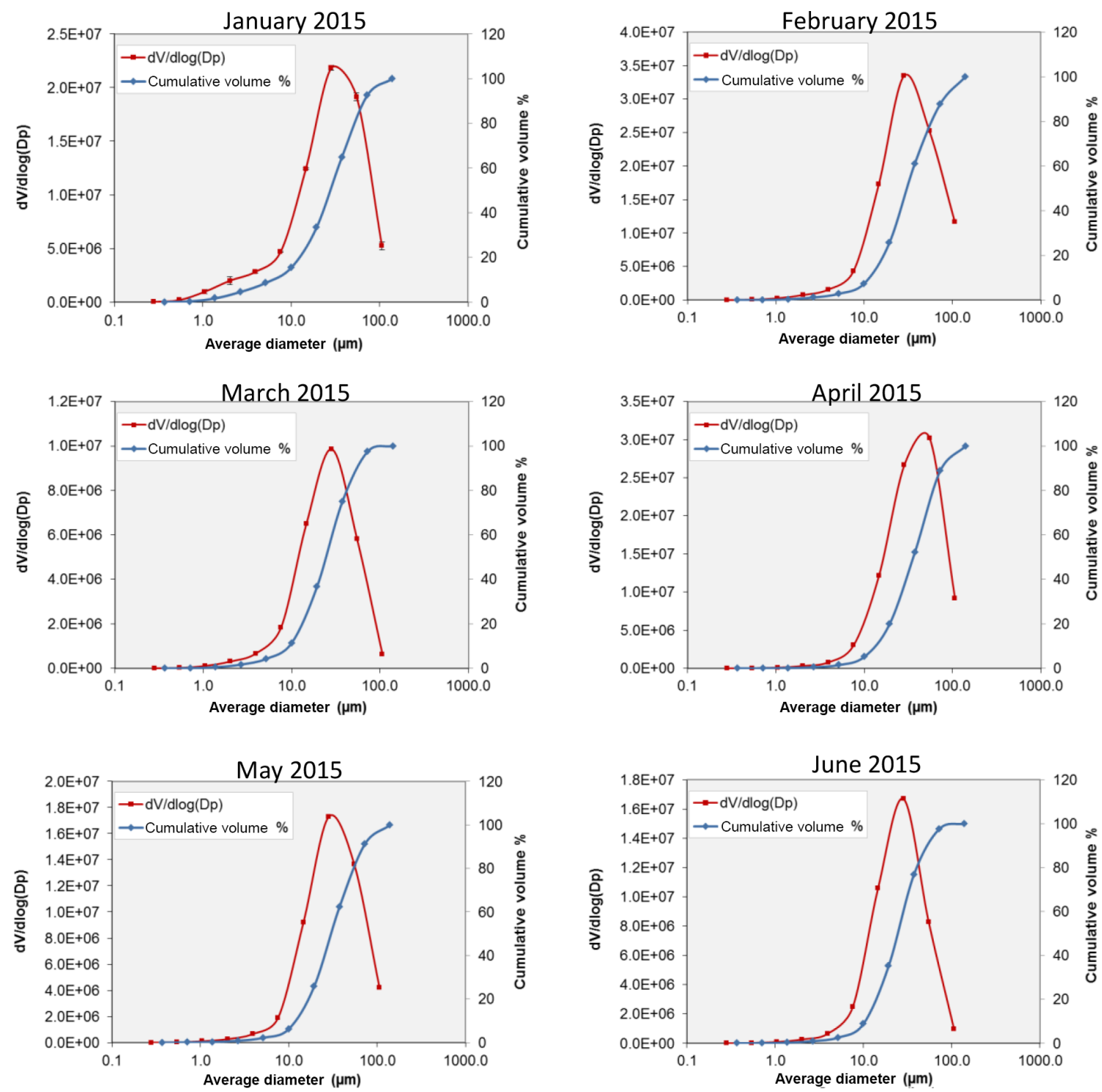

Figure A1. SEM-based particle volume distribution curves for the first 6 months of 2015 (January-June). 

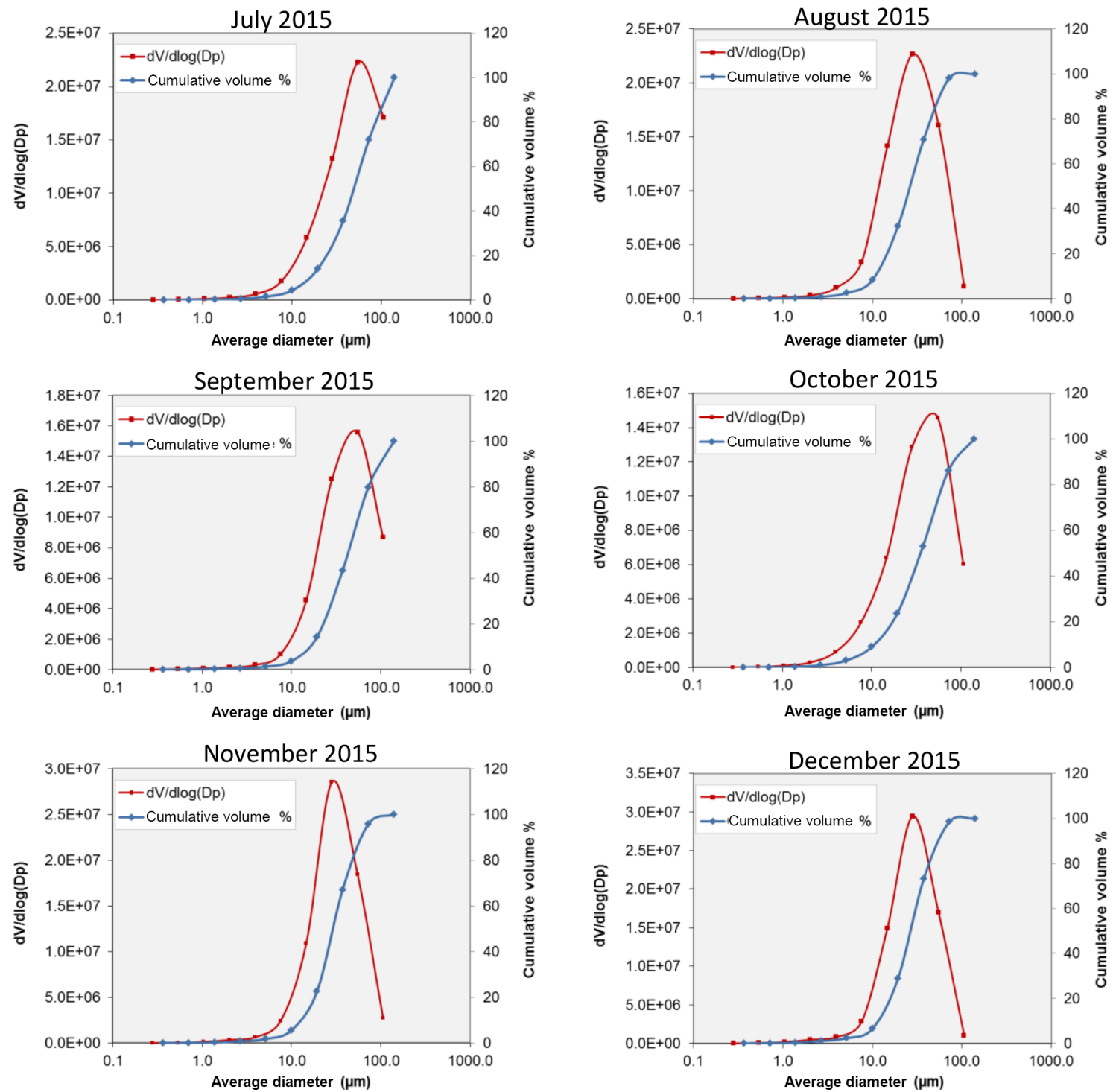

Figure A2. SEM-based particle volume distribution curves for the last 6 months of 2015 (July-December). 


\section{Appendix B}

Table B1. Chemical abundances of deposition samples (January-May 2015).

\begin{tabular}{|c|c|c|c|c|c|c|c|}
\hline Sample & DT1_Jan 2015 & DT1_Feb 2015 & DT1_March 2015 & DT1_April 2015 & DT2_April 2015 & DT1_May 2015 & DT2_May 2015 \\
\hline \multicolumn{8}{|c|}{ Major and minor elements as oxides (\%) } \\
\hline $\mathrm{SiO}_{2}$ & $27.890 \pm 0.050$ & $35.886 \pm 0.065$ & $53.301 \pm 0.089$ & $38.965 \pm 0.063$ & $41.802 \pm 0.073$ & $31.729 \pm 0.055$ & $21.772 \pm 0.039$ \\
\hline $\mathrm{TiO}_{2}$ & $0.466 \pm 0.001$ & $0.530 \pm 0.001$ & $0.679 \pm 0.002$ & $0.464 \pm 0.002$ & $0.599 \pm 0.002$ & $0.486 \pm 0.002$ & $0.451 \pm 0.001$ \\
\hline $\mathrm{Al}_{2} \mathrm{O}_{3}$ & $3.505 \pm 0.035$ & $4.464 \pm 0.050$ & $5.421 \pm 0.097$ & $4.257 \pm 0.115$ & $4.824 \pm 0.081$ & $3.817 \pm 0.079$ & $3.033 \pm 0.026$ \\
\hline $\mathrm{Fe}_{2} \mathrm{O}_{3}$ & $4.480 \pm 0.007$ & $5.119 \pm 0.008$ & $6.312 \pm 0.013$ & $4.309 \pm 0.013$ & $5.091 \pm 0.011$ & $4.150 \pm 0.010$ & $4.104 \pm 0.006$ \\
\hline $\mathrm{MnO}$ & $0.080 \pm 0.001$ & $0.082 \pm 0.002$ & $0.109 \pm 0.004$ & $0.075 \pm 0.005$ & $0.091 \pm 0.003$ & $0.077 \pm 0.003$ & $0.066 \pm 0.001$ \\
\hline $\mathrm{CaO}^{*}$ & $1.989 \pm 0.015$ & $2.097 \pm 0.013$ & $4.157 \pm 0.016$ & $2.369 \pm 0.018$ & $3.066 \pm 0.017$ & $0.753 \pm 0.014$ & $0.847 \pm 0.013$ \\
\hline $\mathrm{K}_{2} \mathrm{O}^{*}$ & $0.484 \pm 0.005$ & $0.604 \pm 0.004$ & $0.864 \pm 0.003$ & $0.705 \pm 0.006$ & $0.798 \pm 0.005$ & $0.542 \pm 0.008$ & $0.432 \pm 0.007$ \\
\hline $\mathrm{P}_{2} \mathrm{O}_{5}$ & $0.417 \pm 0.001$ & $0.150 \pm 0.001$ & $0.010 \pm 0.003$ & $0.332 \pm 0.004$ & $0.306 \pm 0.002$ & $0.474 \pm 0.003$ & $0.429 \pm 0.001$ \\
\hline Total (oxides) & 39.311 & 48.932 & 70.852 & 51.475 & 56.579 & 42.028 & 31.134 \\
\hline \multicolumn{8}{|l|}{ Trace elements (ppm) } \\
\hline V & $107 \pm 1$ & $76 \pm 1$ & $85 \pm 3$ & $106 \pm 4$ & $93 \pm 3$ & $116 \pm 3$ & $99 \pm 1$ \\
\hline $\mathrm{Cr}$ & $92 \pm 3$ & $115 \pm 5$ & $113 \pm 12$ & $101 \pm 15$ & $108 \pm 10$ & $113 \pm 10$ & $120 \pm 2$ \\
\hline $\mathrm{Ni}$ & $78 \pm 2$ & $71 \pm 3$ & $84 \pm 6$ & $68 \pm 8$ & $71 \pm 5$ & $77 \pm 5$ & $57 \pm 1$ \\
\hline $\mathrm{Cu}$ & $81 \pm 3$ & $57 \pm 4$ & $134 \pm 10$ & $125 \pm 13$ & $99 \pm 9$ & $206 \pm 9$ & $64 \pm 2$ \\
\hline $\mathrm{Zn}$ & $223 \pm 5$ & $247 \pm 8$ & $293 \pm 18$ & $287 \pm 23$ & $258 \pm 15$ & $467 \pm 16$ & $219 \pm 4$ \\
\hline As & $0 \pm 3$ & $0 \pm 5$ & $6 \pm 12$ & $0 \pm 15$ & $0 \pm 10$ & $0 \pm 10$ & $0 \pm 2$ \\
\hline $\mathrm{Br}$ & $29 \pm 3$ & $26 \pm 4$ & $42 \pm 10$ & $59 \pm 13$ & $45 \pm 9$ & $34 \pm 9$ & $76 \pm 2$ \\
\hline $\mathrm{Rb}$ & $28 \pm 1$ & $24 \pm 1$ & $16 \pm 3$ & $28 \pm 4$ & $34 \pm 3$ & $30 \pm 3$ & $27 \pm 1$ \\
\hline $\mathrm{Sr}$ & $333 \pm 3$ & $392 \pm 5$ & $514 \pm 11$ & $386 \pm 13$ & $422 \pm 9$ & $303 \pm 9$ & $341 \pm 2$ \\
\hline Y & $1071 \pm 4$ & $36 \pm 4$ & $26 \pm 10$ & $125 \pm 13$ & $46 \pm 9$ & $36 \pm 9$ & $24 \pm 2$ \\
\hline $\mathrm{Zr}$ & $103 \pm 4$ & $98 \pm 6$ & $84 \pm 14$ & $57 \pm 17$ & $139 \pm 12$ & $133 \pm 12$ & $134 \pm 3$ \\
\hline Mo & $0 \pm 5$ & $0 \pm 7$ & $12 \pm 17$ & $4 \pm 21$ & $8 \pm 14$ & $0 \pm 14$ & $0 \pm 3$ \\
\hline $\mathrm{Pb}$ & $15 \pm 5$ & $28 \pm 8$ & $32 \pm 18$ & $66 \pm 23$ & $28 \pm 15$ & $19 \pm 15$ & $28 \pm 3$ \\
\hline \multicolumn{8}{|l|}{ Water-soluble ions (\%) } \\
\hline $\mathrm{NH}_{4}^{+}$ & $0.027 \pm 0.003$ & $0.033 \pm 0.004$ & $0.055 \pm 0.006$ & $0.105 \pm 0.012$ & $0.095 \pm 0.011$ & $0.076 \pm 0.009$ & $0.079 \pm 0.009$ \\
\hline $\mathrm{Na}^{+}$ & $1.585 \pm 0.012$ & $1.267 \pm 0.010$ & $1.053 \pm 0.009$ & $2.952 \pm 0.021$ & $2.897 \pm 0.021$ & $3.519 \pm 0.025$ & $4.473 \pm 0.031$ \\
\hline $\mathrm{K}^{+}$ & $0.230 \pm 0.009$ & $0.170 \pm 0.006$ & $0.114 \pm 0.004$ & $0.262 \pm 0.010$ & $0.207 \pm 0.008$ & $0.371 \pm 0.014$ & $0.296 \pm 0.011$ \\
\hline $\mathrm{Mg}^{2+}$ & $0.338 \pm 0.005$ & $0.265 \pm 0.004$ & $0.188 \pm 0.003$ & $0.488 \pm 0.007$ & $0.400 \pm 0.005$ & $0.558 \pm 0.008$ & $0.744 \pm 0.010$ \\
\hline $\mathrm{Ca}^{2+}$ & $3.311 \pm 0.028$ & $2.718 \pm 0.023$ & $1.813 \pm 0.015$ & $3.745 \pm 0.032$ & $3.220 \pm 0.027$ & $3.780 \pm 0.032$ & $3.560 \pm 0.030$ \\
\hline $\mathrm{Cl}^{-}$ & $2.563 \pm 0.014$ & $2.054 \pm 0.011$ & $1.695 \pm 0.009$ & $4.177 \pm 0.022$ & $4.227 \pm 0.023$ & $3.963 \pm 0.021$ & $5.927 \pm 0.032$ \\
\hline $\mathrm{NO}_{3}^{-}$ & $0.830 \pm 0.030$ & $0.843 \pm 0.031$ & $0.082 \pm 0.004$ & $0.269 \pm 0.010$ & $0.051 \pm 0.004$ & $1.578 \pm 0.057$ & $0.107 \pm 0.005$ \\
\hline $\mathrm{SO}_{4}^{2-}$ & $3.877 \pm 0.034$ & $2.199 \pm 0.019$ & $1.718 \pm 0.015$ & $3.055 \pm 0.027$ & $2.549 \pm 0.022$ & $3.527 \pm 0.031$ & $4.327 \pm 0.038$ \\
\hline Total (ions) & 12.761 & 9.548 & 6.719 & 15.052 & 13.647 & 17.372 & 19.513 \\
\hline Total (oxides + ions) & 52.072 & 58.479 & 77.571 & 66.527 & 70.226 & 59.400 & 50.647 \\
\hline
\end{tabular}

Note: $\mathrm{CaO}^{*}$ and $\mathrm{K}_{2} \mathrm{O}^{*}$ are water insoluble; $\mathrm{P}_{2} \mathrm{O}_{5}^{-}$calculated from total $\mathrm{P}$. 
Table B2. Chemical abundances of deposition samples (May-July 2015).

\begin{tabular}{|c|c|c|c|c|c|c|c|}
\hline Sample & DT3_May 2015 & DT1_June 2015 & DT2_June 2015 & DT3_June 2015 & DT1_July 2015 & DT2_July 2015 & DT3_July 2015 \\
\hline \multicolumn{8}{|c|}{ Major and minor elements as oxides (\%) } \\
\hline $\mathrm{SiO}_{2}$ & $27.167 \pm 0.051$ & $28.318 \pm 0.053$ & $18.530 \pm 0.035$ & $24.158 \pm 0.045$ & $13.820 \pm 0.027$ & $12.693 \pm 0.025$ & $23.221 \pm 0.037$ \\
\hline $\mathrm{TiO}_{2}$ & $0.448 \pm 0.001$ & $0.478 \pm 0.002$ & $0.306 \pm 0.001$ & $0.370 \pm 0.001$ & $0.261 \pm 0.001$ & $0.241 \pm 0.001$ & $0.200 \pm 0.002$ \\
\hline $\mathrm{Al}_{2} \mathrm{O}_{3}$ & $3.777 \pm 0.059$ & $3.692 \pm 0.062$ & $2.919 \pm 0.050$ & $3.067 \pm 0.045$ & $1.886 \pm 0.041$ & $2.030 \pm 0.037$ & $2.694 \pm 0.148$ \\
\hline $\mathrm{Fe}_{2} \mathrm{O}_{3}$ & $3.972 \pm 0.008$ & $3.906 \pm 0.008$ & $2.782 \pm 0.006$ & $3.346 \pm 0.006$ & $2.287 \pm 0.005$ & $2.154 \pm 0.005$ & $1.935 \pm 0.014$ \\
\hline $\mathrm{MnO}$ & $0.083 \pm 0.002$ & $0.077 \pm 0.002$ & $0.050 \pm 0.002$ & $0.068 \pm 0.002$ & $0.050 \pm 0.002$ & $0.044 \pm 0.002$ & $0.050 \pm 0.007$ \\
\hline $\mathrm{CaO}^{*}$ & $1.983 \pm 0.016$ & $1.681 \pm 0.014$ & $1.179 \pm 0.013$ & $1.745 \pm 0.014$ & $0.427 \pm 0.010$ & $1.179 \pm 0.011$ & $1.148 \pm 0.013$ \\
\hline $\mathrm{K}_{2} \mathrm{O}^{*}$ & $0.508 \pm 0.006$ & $0.513 \pm 0.007$ & $0.366 \pm 0.008$ & $0.467 \pm 0.006$ & $0.208 \pm 0.008$ & $0.226 \pm 0.008$ & $0.359 \pm 0.009$ \\
\hline $\mathrm{P}_{2} \mathrm{O}_{5}$ & $0.170 \pm 0.002$ & $0.590 \pm 0.002$ & $0.383 \pm 0.002$ & $0.389 \pm 0.001$ & $0.753 \pm 0.002$ & $0.457 \pm 0.001$ & $0.288 \pm 0.005$ \\
\hline Total (oxides) & 38.108 & 39.254 & 26.514 & 33.609 & 19.692 & 19.024 & 29.895 \\
\hline \multicolumn{8}{|l|}{ Trace elements (ppm) } \\
\hline V & $88 \pm 2$ & $111 \pm 2$ & $86 \pm 2$ & $91 \pm 1$ & $115 \pm 1$ & $111 \pm 1$ & $77 \pm 5$ \\
\hline $\mathrm{Cr}$ & $71 \pm 7$ & $96 \pm 7$ & $65 \pm 6$ & $82 \pm 5$ & $160 \pm 5$ & $60 \pm 5$ & $67 \pm 21$ \\
\hline $\mathrm{Ni}$ & $62 \pm 3$ & $84 \pm 4$ & $49 \pm 3$ & $72 \pm 3$ & $133 \pm 3$ & $71 \pm 2$ & $91 \pm 11$ \\
\hline $\mathrm{Cu}$ & $56 \pm 6$ & $134 \pm 7$ & $59 \pm 5$ & $49 \pm 5$ & $209 \pm 5$ & $62 \pm 4$ & $25 \pm 19$ \\
\hline $\mathrm{Zn}$ & $251 \pm 11$ & $430 \pm 12$ & $297 \pm 9$ & $255 \pm 8$ & $515 \pm 9$ & $244 \pm 7$ & $180 \pm 32$ \\
\hline As & $0 \pm 7$ & $0 \pm 7$ & $0 \pm 6$ & $0 \pm 5$ & $0 \pm 5$ & $0 \pm 5$ & $0 \pm 21$ \\
\hline $\mathrm{Br}$ & $58 \pm 6$ & $62 \pm 7$ & $100 \pm 5$ & $64 \pm 5$ & $62 \pm 5$ & $88 \pm 4$ & $37 \pm 19$ \\
\hline $\mathrm{Rb}$ & $24 \pm 2$ & $35 \pm 2$ & $16 \pm 2$ & $23 \pm 1$ & $17 \pm 1$ & $12 \pm 1$ & $8 \pm 5$ \\
\hline $\mathrm{Sr}$ & $392 \pm 7$ & $322 \pm 7$ & $276 \pm 6$ & $291 \pm 5$ & $233 \pm 5$ & $268 \pm 4$ & $284 \pm 19$ \\
\hline $\mathrm{Y}$ & $14 \pm 6$ & $23 \pm 7$ & $14 \pm 5$ & $19 \pm 5$ & $7 \pm 5$ & $12 \pm 4$ & $23 \pm 19$ \\
\hline $\mathrm{Zr}$ & $123 \pm 8$ & $149 \pm 9$ & $112 \pm 7$ & $82 \pm 6$ & $76 \pm 6$ & $83 \pm 6$ & $88 \pm 24$ \\
\hline Mo & $0 \pm 10$ & $0 \pm 10$ & $0 \pm 8$ & $0 \pm 7$ & $0 \pm 7$ & $0 \pm 6$ & $0 \pm 29$ \\
\hline $\mathrm{Pb}$ & $18 \pm 10$ & $12 \pm 11$ & $15 \pm 9$ & $17 \pm 8$ & $22 \pm 8$ & $30 \pm 7$ & $45 \pm 32$ \\
\hline \multicolumn{8}{|l|}{ Water-soluble ions (\%) } \\
\hline $\mathrm{NH}_{4}^{+}$ & $0.091 \pm 0.010$ & $0.125 \pm 0.014$ & $0.120 \pm 0.013$ & $0.100 \pm 0.011$ & $0.088 \pm 0.010$ & $0.032 \pm 0.004$ & $0.109 \pm 0.012$ \\
\hline $\mathrm{Na}^{+}$ & $4.509 \pm 0.031$ & $3.505 \pm 0.025$ & $5.875 \pm 0.041$ & $2.834 \pm 0.020$ & $3.466 \pm 0.024$ & $5.538 \pm 0.038$ & $5.360 \pm 0.037$ \\
\hline $\mathrm{K}^{+}$ & $0.276 \pm 0.010$ & $0.312 \pm 0.012$ & $0.352 \pm 0.013$ & $0.256 \pm 0.010$ & $0.339 \pm 0.013$ & $0.360 \pm 0.013$ & $0.390 \pm 0.015$ \\
\hline $\mathrm{Mg}^{2+}$ & $0.572 \pm 0.008$ & $0.559 \pm 0.008$ & $0.947 \pm 0.013$ & $0.453 \pm 0.006$ & $0.582 \pm 0.008$ & $0.878 \pm 0.012$ & $0.628 \pm 0.009$ \\
\hline $\mathrm{Ca}^{2+}$ & $3.582 \pm 0.030$ & $3.094 \pm 0.026$ & $3.341 \pm 0.028$ & $3.092 \pm 0.026$ & $2.767 \pm 0.024$ & $2.642 \pm 0.022$ & $2.833 \pm 0.024$ \\
\hline $\mathrm{Cl}^{-}$ & $6.828 \pm 0.037$ & $3.648 \pm 0.020$ & $7.799 \pm 0.042$ & $3.562 \pm 0.019$ & $3.141 \pm 0.017$ & $6.005 \pm 0.032$ & $7.612 \pm 0.041$ \\
\hline $\mathrm{NO}_{3}^{-}$ & $1.328 \pm 0.048$ & $0.595 \pm 0.022$ & $0.349 \pm 0.013$ & $0.939 \pm 0.034$ & $1.573 \pm 0.057$ & $1.702 \pm 0.061$ & $1.864 \pm 0.067$ \\
\hline $\mathrm{SO}_{4}^{2-}$ & $3.649 \pm 0.032$ & $2.965 \pm 0.026$ & $4.878 \pm 0.043$ & $2.483 \pm 0.022$ & $2.923 \pm 0.026$ & $4.424 \pm 0.039$ & $3.087 \pm 0.027$ \\
\hline Total (ions) & 20.836 & 14.804 & 23.663 & 13.719 & 14.879 & 21.580 & 21.882 \\
\hline Total (oxides + ions) & 58.944 & 54.058 & 50.177 & 47.328 & 34.571 & 40.605 & 51.777 \\
\hline
\end{tabular}

Note: $\mathrm{CaO}^{*}$ and $\mathrm{K}_{2} \mathrm{O}^{*}$ are water insoluble; $\mathrm{P}_{2} \mathrm{O}_{5}^{-}$calculated from total $\mathrm{P}$. 
Table B3. Chemical abundances of deposition samples (August-October 2015).

\begin{tabular}{|c|c|c|c|c|c|c|c|}
\hline Sample & DT1_Aug 2015 & DT2_Aug 2015 & DT3_Aug 2015 & DT1_Sept 2015 & DT2_Sept 2015 & DT3_Sept 2015 & DT1_Oct 2015 \\
\hline \multicolumn{8}{|c|}{ Major and minor elements as oxides (\%) } \\
\hline $\mathrm{SiO}_{2}$ & $34.862 \pm 0.061$ & $33.619 \pm 0.058$ & $29.244 \pm 0.054$ & $50.971 \pm 0.083$ & $11.690 \pm 0.024$ & $42.544 \pm 0.074$ & $41.270 \pm 0.067$ \\
\hline $\mathrm{TiO}_{2}$ & $0.591 \pm 0.001$ & $0.469 \pm 0.002$ & $0.422 \pm 0.002$ & $0.605 \pm 0.003$ & $0.206 \pm 0.001$ & $0.609 \pm 0.002$ & $0.496 \pm 0.002$ \\
\hline $\mathrm{Al}_{2} \mathrm{O}_{3}$ & $4.021 \pm 0.033$ & $3.773 \pm 0.078$ & $3.514 \pm 0.068$ & $5.057 \pm 0.124$ & $3.628 \pm 0.053$ & $5.114 \pm 0.081$ & $4.374 \pm 0.115$ \\
\hline $\mathrm{Fe}_{2} \mathrm{O}_{3}$ & $5.488 \pm 0.008$ & $4.186 \pm 0.010$ & $3.878 \pm 0.009$ & $5.479 \pm 0.015$ & $2.206 \pm 0.006$ & $5.540 \pm 0.011$ & $4.592 \pm 0.013$ \\
\hline $\mathrm{MnO}$ & $0.095 \pm 0.001$ & $0.082 \pm 0.003$ & $0.068 \pm 0.003$ & $0.102 \pm 0.005$ & $0.048 \pm 0.002$ & $0.096 \pm 0.003$ & $0.081 \pm 0.005$ \\
\hline $\mathrm{CaO}^{*}$ & $1.772 \pm 0.014$ & $5.067 \pm 0.017$ & $3.423 \pm 0.014$ & $4.909 \pm 0.019$ & $3.273 \pm 0.006$ & $0.598 \pm 0.014$ & $2.690 \pm 0.018$ \\
\hline $\mathrm{K}_{2} \mathrm{O}^{*}$ & $0.598 \pm 0.003$ & $0.850 \pm 0.002$ & $0.709 \pm 0.003$ & $0.988 \pm 0.002$ & $0.000 \pm 0.014$ & $0.853 \pm 0.003$ & $0.756 \pm 0.004$ \\
\hline $\mathrm{P}_{2} \mathrm{O}_{5}$ & $0.249 \pm 0.001$ & $0.158 \pm 0.002$ & $0.076 \pm 0.002$ & $0.000 \pm 0.004$ & $0.000 \pm 0.001$ & $0.194 \pm 0.002$ & $0.047 \pm 0.003$ \\
\hline Total (oxides) & 47.676 & 48.204 & 41.334 & 68.110 & 21.051 & 55.547 & 54.306 \\
\hline \multicolumn{8}{|l|}{ Trace elements (ppm) } \\
\hline V & $122 \pm 1$ & $110 \pm 3$ & $42 \pm 2$ & $51 \pm 4$ & $19 \pm 2$ & $93 \pm 2$ & $0 \pm 4$ \\
\hline $\mathrm{Cr}$ & $116 \pm 3$ & $59 \pm 10$ & $76 \pm 9$ & $96 \pm 16$ & $46 \pm 6$ & $93 \pm 10$ & $152 \pm 15$ \\
\hline $\mathrm{Ni}$ & $91 \pm 1$ & $71 \pm 5$ & $54 \pm 4$ & $61 \pm 8$ & $29 \pm 3$ & $76 \pm 5$ & $73 \pm 8$ \\
\hline $\mathrm{Cu}$ & $55 \pm 2$ & $76 \pm 9$ & $41 \pm 7$ & $55 \pm 14$ & $32 \pm 5$ & $86 \pm 8$ & $40 \pm 13$ \\
\hline $\mathrm{Zn}$ & $194 \pm 4$ & $226 \pm 15$ & $127 \pm 13$ & $157 \pm 24$ & $107 \pm 9$ & $339 \pm 15$ & $185 \pm 23$ \\
\hline As & $0 \pm 3$ & $0 \pm 10$ & $0 \pm 9$ & $0 \pm 16$ & $0 \pm 6$ & $0 \pm 10$ & $0 \pm 15$ \\
\hline $\mathrm{Br}$ & $20 \pm 2$ & $16 \pm 9$ & $34 \pm 7$ & $17 \pm 14$ & $715 \pm 7$ & $58 \pm 8$ & $64 \pm 13$ \\
\hline $\mathrm{Rb}$ & $22 \pm 1$ & $43 \pm 3$ & $12 \pm 2$ & $47 \pm 4$ & $18 \pm 2$ & $38 \pm 2$ & $24 \pm 4$ \\
\hline $\mathrm{Sr}$ & $441 \pm 3$ & $369 \pm 9$ & $257 \pm 7$ & $394 \pm 14$ & $179 \pm 5$ & $345 \pm 9$ & $331 \pm 13$ \\
\hline Y & $18 \pm 2$ & $9 \pm 9$ & $25 \pm 7$ & $23 \pm 14$ & $8 \pm 5$ & $14 \pm 8$ & $18 \pm 13$ \\
\hline $\mathrm{Zr}$ & $141 \pm 3$ & $133 \pm 12$ & $125 \pm 10$ & $123 \pm 20$ & $62 \pm 7$ & $127 \pm 12$ & $99 \pm 17$ \\
\hline Mo & $0 \pm 4$ & $0 \pm 14$ & $0 \pm 12$ & $0 \pm 23$ & $1 \pm 8$ & $3 \pm 13$ & $17 \pm 21$ \\
\hline $\mathrm{Pb}$ & $4 \pm 4$ & $58 \pm 15$ & $63 \pm 13$ & $36 \pm 24$ & $12 \pm 9$ & $28 \pm 14$ & $46 \pm 23$ \\
\hline \multicolumn{8}{|l|}{ Water-soluble ions (\%) } \\
\hline $\mathrm{NH}_{4}^{+}$ & $0.025 \pm 0.003$ & $0.018 \pm 0.002$ & $0.021 \pm 0.002$ & $0.021 \pm 0.003$ & $0.027 \pm 0.003$ & $0.024 \pm 0.003$ & $0.013 \pm 0.002$ \\
\hline $\mathrm{Na}^{+}$ & $1.044 \pm 0.009$ & $0.481 \pm 0.006$ & $1.144 \pm 0.009$ & $0.756 \pm 0.007$ & $12.685 \pm 0.087$ & $0.862 \pm 0.008$ & $2.134 \pm 0.016$ \\
\hline $\mathrm{K}^{+}$ & $0.116 \pm 0.004$ & $0.094 \pm 0.004$ & $0.133 \pm 0.005$ & $0.106 \pm 0.004$ & $0.625 \pm 0.023$ & $0.123 \pm 0.005$ & $0.192 \pm 0.007$ \\
\hline $\mathrm{Mg}^{2+}$ & $0.213 \pm 0.003$ & $0.133 \pm 0.002$ & $0.193 \pm 0.003$ & $0.146 \pm 0.002$ & $1.732 \pm 0.024$ & $0.261 \pm 0.004$ & $0.425 \pm 0.006$ \\
\hline $\mathrm{Ca}^{2+}$ & $3.101 \pm 0.026$ & $1.772 \pm 0.015$ & $1.840 \pm 0.016$ & $2.143 \pm 0.018$ & $1.280 \pm 0.011$ & $1.928 \pm 0.016$ & $3.415 \pm 0.029$ \\
\hline $\mathrm{Cl}^{-}$ & $1.624 \pm 0.009$ & $0.588 \pm 0.004$ & $1.460 \pm 0.008$ & $1.216 \pm 0.007$ & $23.054 \pm 0.123$ & $1.034 \pm 0.006$ & $3.267 \pm 0.018$ \\
\hline $\mathrm{NO}_{3}^{-}$ & $1.045 \pm 0.038$ & $0.418 \pm 0.015$ & $0.943 \pm 0.034$ & $0.396 \pm 0.015$ & $0.007 \pm 0.003$ & $0.004 \pm 0.003$ & $0.009 \pm 0.003$ \\
\hline $\mathrm{SO}_{4}^{2-}$ & $3.241 \pm 0.028$ & $1.425 \pm 0.012$ & $1.591 \pm 0.014$ & $2.047 \pm 0.018$ & $2.778 \pm 0.024$ & $1.743 \pm 0.015$ & $3.042 \pm 0.027$ \\
\hline Total (ions) & 10.410 & 4.930 & 7.324 & 6.831 & 42.187 & 5.980 & 12.496 \\
\hline Total (oxides + ions) & 58.085 & 53.134 & 48.658 & 74.941 & 63.238 & 61.527 & 66.802 \\
\hline
\end{tabular}

Note: $\mathrm{CaO}^{*}$ and $\mathrm{K}_{2} \mathrm{O}^{*}$ are water insoluble; $\mathrm{P}_{2} \mathrm{O}_{5}^{-}$calculated from total $\mathrm{P}$. 


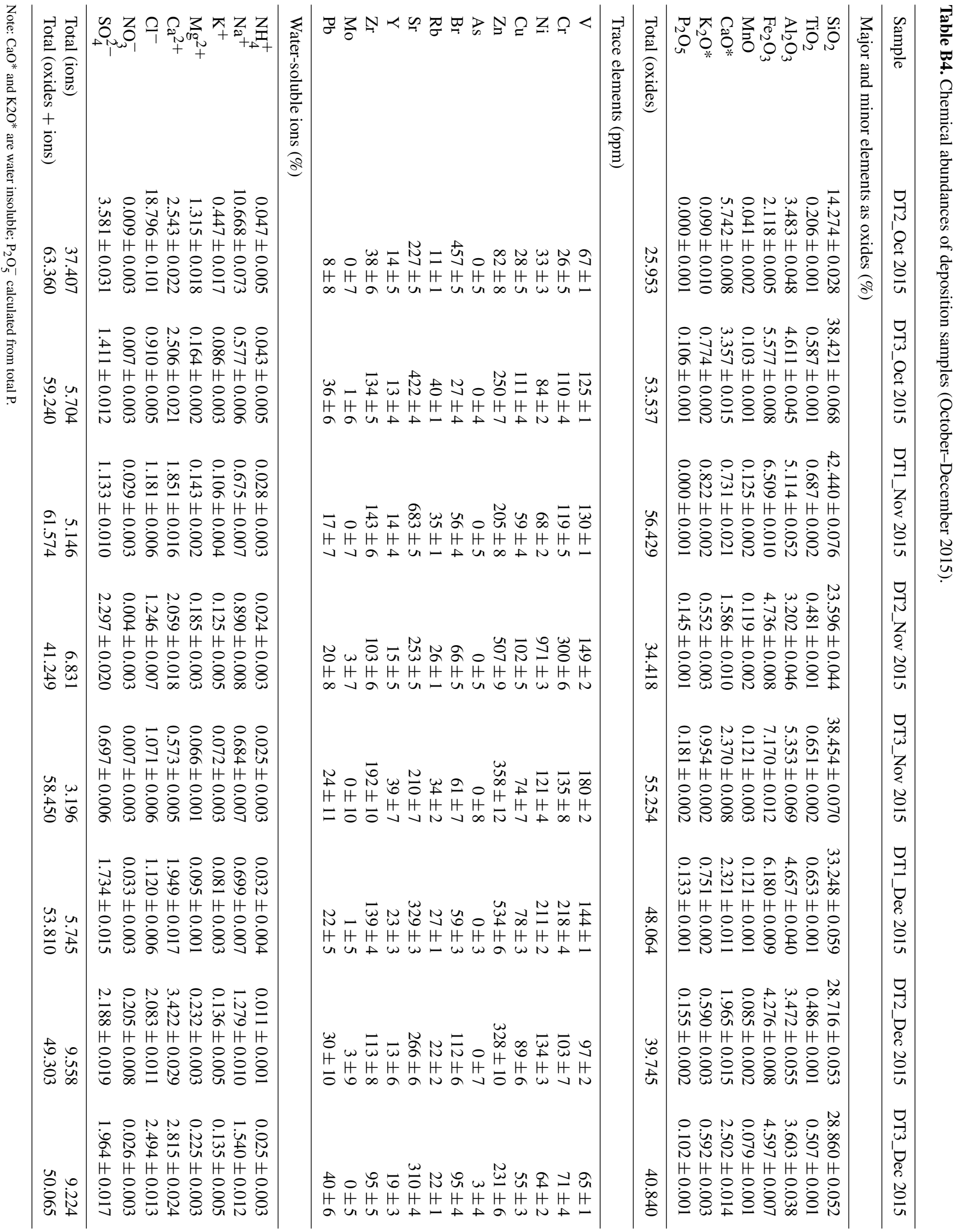




\author{
The Supplement related to this article is available \\ online at https://doi.org/10.5194/acp-17-11467-2017- \\ supplement.
}

Author contributions. JE was responsible for the sample analysis and data compilation; GS formulated the problem, designed the research project, and supported experimental activities; JP performed collection and conducted the freeze drying of the samples, as well as performing part of the XRD analysis. TL performed the SEM-based individual particle analysis; AA assembled the meteorological and visibility data; IS assembled the AERONET optical data; and JE, GS, JP, AA, and IS compiled different parts of the manuscript.

Competing interests. The authors declare that they have no conflict of interest.

Acknowledgements. This research, including the chemical and mineralogical analysis, is supported by internal funding from the King Abdullah University of Science and Technology (KAUST). We acknowledge the contributions from the collaborating Core Labs at KAUST, the Desert Research Institute, and RJ Lee Group, Inc. This research is supported by the Supercomputing Laboratory at KAUST. The valuable comments by the co-editor and three anonymous reviewers towards improving the manuscript are greatly appreciated.

Edited by: Yves Balkanski

Reviewed by: three anonymous referees

\section{References}

Acosta, F., Ngugi, D. K., and Stingl, U.: Diversity of picoeukaryotes at an oligotrophic site off the Northeastern Red Sea Coast, Aquatic Biosystems, 9, 16, https://doi.org/10.1186/2046-9063-916, 2013.

Al-Awadhi, J. M.: Dust fallout characteristics in Kuwait: a case study, Kuwait J. Sci. Eng., 32, 135-151, 2005.

Al-Awadhi, J. M. and AlShuaibi, A. A.: Dust fallout in Kuwait city: Deposition and characterization, Sci. Total Environ., 461, 139148, https://doi.org/10.1016/j.scitotenv.2013.03.052, 2013.

Alduchov, O. A. and Eskridge, R. E.: Improved Magnus Form Approximation of saturation vapor pressure, J. Appl. Meteorol., 35, 601-609, 1996.

Anisimov, A., Tao, W., Stenchikov, G., Kalenderski, S., Prakash, P. J., Yang, Z.-L., and Shi, M.: Quantifying local-scale dust emission from the Arabian Red Sea coastal plain, Atmos. Chem. Phys., 17, 993-1015, https://doi.org/10.5194/acp-17-993-2017, 2017.

August, E. F.: Ueber die Berechnung der Expansivkraft des Wasserdunstes, Annalen der Physik und Chemie, 13, 122-137, 1828.

Bennett, C. M., McKendry, I. G., Kelly, S., Denike, K., and Koch, T.: Impact of the 1998 Gobi dust event on hospital admissions in the Lower Fraser Valley, British Columbia, Sci. Total Environ.,
366, 918-925, https://doi.org/10.1016/j.scitotenv.2005.12.025, 2006.

Bennion, P., Hubbard, R., O'Hara, S., Wiggs, G., Wegerdt, J., Lewis, S., Small, I., van der Meer, J., and Upshur, R.: The impact of airborne dust on respiratory health in children living in the Aral Sea region, Int. J. Epidemiol., 36, 1103-1110, https://doi.org/10.1093/ije/dym195, 2007.

Bergametti, G. and Forêt, G.: Dust Deposition, in: Mineral Dust. A Key Player in the Earth System, edited by: Knippertz, P. and Stuut, J.-B. W., Springer, Dordrecht, 179-200, 2014.

Brindley, H., Osipov, S., Bantges, R., Smirnov, A., Banks, J., Levy, R., Jish Prakash, P., and Stenchikov, G.: An assessment of the quality of aerosol retrievals overthe Red Sea and evaluation of the climatological cloud-free dust direct radiative effect in the region, J. Geophys. Res.-Atmos., 120, 10862-10878, https://doi.org/10.1002/2015JD023282, 2015.

Buseck, P. R., Jacob, D. J., Pósfai, M., Li, J., and Anderson, J. R.: Minerals in the air: An environmental perspective, Int. Geol. Rev., 42, 577-593, https://doi.org/10.1080/00206810009465101, 2000.

Caquineau, S., Magonthier, M.-C., Gaudichet, A., and Gomes, L.: An improved procedure for the X-ray diffraction analysis of lowmass atmospheric dust samples, Eur. J. Mineral., 9, 157-166, 1997.

Chow, J. C. and Watson, J. G.: Ion Chromatography in elemental analysis of airborne particles, in: Elemental Analysis of Airborne Particles, edited by: Landsberger, S. and Creatchman, M., Gordon and Breach Science, Amsterdam, 97-137, 1999.

Chung, F. H.: Quantitative interpretation of X-ray diffraction patterns of mixtures. I. Matrix-flushing method for quantitative multicomponent analysis, J. Appl. Crystallogr., 7, 519-525, https://doi.org/10.1107/S0021889874010375, 1974.

De Longueville, F., Hountondji, Y. C., Henry, S., and Ozer, P.: What do we know about effects of desert dust on air quality and human health in West Africa compared to other regions?, Sci. Total Environ., 409, 1-8, https://doi.org/10.1016/j.scitotenv.2010.09.025, 2010.

Edgell, H. S.: Arabian Deserts. Nature, Origin and Evolution, Springer, Dordrecht, The Netherlands, 592 pp., 2006.

Engelbrecht, J. P., McDonald, E. V., Gillies, J. A., Jayanty, R. K. M., Casuccio, G., and Gertler, A. W.: Characterizing mineral dusts and other aerosols from the Middle East - Part 1: Ambient sampling, Inhal. Toxicol., 21, 297-326, https://doi.org/10.1080/08958370802464273, 2009a.

Engelbrecht, J. P., McDonald, E. V., Gillies, J. A., Jayanty, R. K. M., Casuccio, G., and Gertler, A. W.: Characterizing mineral dusts and other aerosols from the Middle East - Part 2: Grab samples and re-suspensions, Inhal. Toxicol., 21, 327-336, https://doi.org/10.1080/08958370802464299, 2009b.

Engelbrecht, J. P., Moosmüller, H., Pincock, S., Jayanty, R. K. M., Lersch, T., and Casuccio, G.: Technical note: Mineralogical, chemical, morphological, and optical interrelationships of mineral dust re-suspensions, Atmos. Chem. Phys., 16, 10809-10830, https://doi.org/10.5194/acp-16-10809-2016, 2016.

Esteve, V., Rius, J., Ochando, L. E., and Amigó, J. M.: Quantitative $\mathrm{x}$-ray diffraction phase analysis of coarse airborne particulate collected by cascade impactor sampling, Atmos. Environ., 31, 3963-3967, https://doi.org/10.1016/S1352-2310(97)002574, 1997. 
Formenti, P., Rajot, J. L., Desboeufs, K., Caquineau, S., Chevaillier, S., Nava, S., Gaudichet, A., Journet, E., Triquet, S., Alfaro, S., Chiari, M., Haywood, J., Coe, H., and Highwood, E.: Regional variability of the composition of mineral dust from western Africa: Results from the AMMA SOP0/DABEX and DODO field campaigns, J. Geophys. Res.-Atmos., 113, D00C13, https://doi.org/10.1029/2008JD009903, 2008.

Fryrear, D. W.: Long-term effect of erosion and cropping on soil productivity, in: Desert Dust: Origin, Characteristics, and Effect on Man, edited by: Péwé, T. L., GSA Special Papers, Geological Society of America, 186, 253-260, https://doi.org/10.1130/SPE186-p253, 1981.

Ginoux, P., Prospero, J. M., Gill, T. E., Hsu, N. C., and Zhao, M.: Global-scale attribution of anthropogenic and natural dust sources and their emission rates based on MODIS Deep Blue aerosol products, Rev. Geophys., 50, RG3005, https://doi.org/10.1029/2012RG000388, 2012.

Goossens, D.: Quantification of the dry aeolian deposition of dust on horizontalsurfaces: an experimental comparison of theory and measurements, Sedimentology, 52, 859-873, https://doi.org/10.1111/j.1365-3091.2005.00719.x, 2005.

Goossens, D. and Offer, Z. Y.: Wind tunnel and field calibration of six aeolian dust samplers, Atmos. Environ., 34, 1043-1057, https://doi.org/10.1016/S1352-2310(99)00376-3, 2000.

Goossens, D. and Rajot, J. L.: Techniques to measure the dry aeolian deposition of dust in arid and semi-arid landscapes: a comparative study in West Niger, Earth Surface Processes and Landforms, 33, 178-195, https://doi.org/10.1002/esp.1533, 2008.

Goossens, D. and Van Kerschaever, E.: Aeolian dust deposition on photovoltaic solar cells: The effects of wind velocity and airborne dust concentration on cell performance, Sol. Energy, 66, 277289, 1999.

Goossens, D., Offer, Z., and London, G.: Wind tunnel and field calibration of five aeolian sand traps, Geomorphology, 35, 233-252, https://doi.org/10.1016/S0169-555X(00)00041-6, 2000.

Goudie, A. S. and Middleton, N. J.: Desert Dust in the Global System, Springer, Germany, 287 pp., 2006.

Hagen, L. J. and Woodruff, N. P.: Air pollution in the Great Plains, Atmos. Environ., 7, 323-332, 1973.

Hall, D. J., Upton, S. L., and Marsland, G. W.: Improvements in dust gauge design, in: Measurements of Airborne Pollutants, edited by: Couling, S., Butterworth, Heinemann, London, 1993.

Hamou, S., Zine, S., and Abdellah, R.: Efficiency of PV module under real working conditions, Energy Procedia, 50, 553-558, 2014.

Haywood, J. and Boucher, O.: Estimates of the direct and indirect radiative forcing due to tropospheric aerosols: A review, Rev. Geophys., 38, 513-543, https://doi.org/10.1029/1999RG000078, 2000.

Hsu, N. C., Tsay, S. C., King, M. D., and Herman, J. R.: Aerosol properties over bright-reflecting source regions, IEEE T. Geosci. Remote, 42, 557-569, https://doi.org/10.1109/TGRS.2004.824067, 2004.

Huang, J., Minnis, P., Lin, B., Wang, T., Yi, Y., Hu, Y., SunMack, S., and Ayers, K.: Possible influences of Asian dust aerosols on cloud properties and radiative forcing observed from MODIS and CERES, Geophys. Res. Lett., 33, L06824, https://doi.org/10.1029/2005GL024724, 2006.
Ilse, K., Werner, M., Naumann, V., Figgis, B. W., Hagendorf, C., and Bagdahn, J.: Microstructural analysis of the cementation process during soiling on glass surfaces in arid and semi-arid climates, Phys. Status Solidi-R., 10, 525-529, https://doi.org/10.1002/pssr.201600152, 2016.

Jiang, H., Farrar, J. T., Beardsley, R. C., Chen, R., and Chen, C.: Zonal surface wind jets across the Red Sea due to mountain gap forcing along both sides of the Red Sea, Geophys. Res. Lett., 36, L19605, https://doi.org/10.1029/2009GL040008, 2009.

Jickells, T. D., An, Z. S., Andersen, K. K., Baker, A. R., Bergametti, G., Brooks, N., Cao, J. J., Boyd, P. W., Duce, R. A., Hunter, K. A., Kawahata, H., Kubilay, N., laRoche, J., Liss, P. S., Mahowald, N., Prospero, J. M., Ridgwell, A. J., Tegen, I., and Torres, R.: Global iron connections between desert dust, ocean biogeochemistry, and climate, Science, 308, 67-71, https://doi.org/10.1126/science.1105959, 2005.

Jish Prakash, P., Stenchikov, G., Kalenderski, S., Osipov, S., and Bangalath, H.: The impact of dust storms on the Arabian Peninsula and the Red Sea, Atmos. Chem. Phys., 15, 199-222, https://doi.org/10.5194/acp-15-199-2015, 2015.

Jish Prakash, P., Stenchikov, G., Tao, W., Yapici, T., Warsama, B., and Engelbrecht, J. P.: Arabian Red Sea coastal soils as potential mineral dust sources, Atmos. Chem. Phys., 16, 11991-12004, https://doi.org/10.5194/acp-16-11991-2016, 2016.

Kalenderski, S. and Stenchikov, G.: High-resolution regional modeling of summertime transport and impact of African dust over the Red Sea and Arabian Peninsula, J. Geophys. Res.-Atmos., 121, 6435-6458, https://doi.org/10.1002/2015JD024480, 2016.

Kalenderski, S., Stenchikov, G., and Zhao, C.: Modeling a typical winter-time dust event over the Arabian Peninsula and the Red Sea, Atmos. Chem. Phys., 13, 1999-2014, https://doi.org/10.5194/acp-13-1999-2013, 2013.

Kandler, K., Benker, N., Bundke, U., Cuevas, E., Ebert, M., Knippertz, P., Rodríguez, S., Schütz, L., and Weinbruch, S.: Chemical composition and complex refractive index of Saharan mineral dust at Izaña, Tenerife (Spain) derived by electron microscopy, Atmos. Environ., 41, 8058-8074, 2007.

Kandler, K., Schütz, L., Deutscher, C., Ebert, M., Hofmann, H., Jäckel, S., Jaenicke, R., Knippertz, P., Lieke, K., Massling, A., Petzold, A., Schladitz, A., Weinzierl, B., Wiedensohler, A., Zorn, S., and Weinbruch, S.: Size distribution, mass concentration, chemical and mineralogical composition and derived optical parameters of the boundary layer aerosol at Tinfou, Morocco, during SAMUM 2006, Tellus B, 61, 32-50, 2009.

Kavouras, I. G., Etyemezian, V., DuBois, D. W., Xu, J., and Pitchford, M.: Source reconciliation of atmospheric dust causing visibility impairment in class I areas of the western United States, J. Geophys. Res.-Atmos., 114, D02308, 2009.

Khalaf, F. and Al-Hashash, M.: Aeolian sedimentation in the northwestern part of the Arabian Gulf, J. Arid Environ., 6, 319-332, 1983.

Kumar, R., Barth, M. C., Pfister, G. G., Naja, M., and Brasseur, G. P.: WRF-Chem simulations of a typical pre-monsoon dust storm in northern India: influences on aerosol optical properties and radiation budget, Atmos. Chem. Phys., 14, 2431-2446, https://doi.org/10.5194/acp-14-2431-2014, 2014.

Magnus, G.: Versuche über die Spannkräfte des Wasserdampfs, Annalen der Physik und Chemie, 61, 225-247, https://doi.org/10.1002/andp.18441370202, 1844. 
Mahowald, N., Engelstaedter, S., Luo, C., Sealy, A., Artaxo, P., Benitez-Nelson, C., Bonnet, S., Chen, Y., Chuang, P. Y., Cohen, D. D., Dulac, F., Herut, B., Johansen, A. M., Kubilay, N., Losno, R., Maenhaut, W., Paytan, A., Prospero, J. M., Shank, L. M., and Siefert, R. L.: Atmospheric iron deposition: Global distribution, variability and human perturbations, Annual Review of Marine Science, 1, 245-278, https://doi.org/10.1146/annurev.marine.010908.163727, 2009.

Mejia, F., Kleissl, J., and Bosch, J. L.: The effect of dust on solar photovoltaic systems, Energy Procedia, 49, 2370-2376, https://doi.org/10.1016/j.egypro.2014.03.251, 2014.

Menéndez, I., Derbyshire, E., Carrillo, T., Caballero, E., Engelbrecht, J. P., Romero, L. E., Mayer, P. L., de Castro, F. R., and Mangas, J.: Saharan dust and the impact on adult and elderly allergic patients: the effect of threshold values in the northern sector of Gran Canaria, Spain, Int. J. Environ. Heal. R., 27, 144-160, https://doi.org/10.1080/09603123.2017.1292496, 2017.

Modaihsh, A. S.: Characteristics and composition of the falling dust sediments on Riyadh City, Saudi Arabia, J. Arid Environ., 36, 211-223, https://doi.org/10.1006/jare.1996.0225, 1997.

Modaihsh, A. S. and Mahjoub, M. O.: Falling dust characteristics in Riyadh City, Saudi Arabia during winter months, Asia-Pacific Chemical, Biological \& Engineering Society Procedia, 5, 50-58, https://doi.org/10.1016/j.apcbee.2013.05.010, 2013.

Moosmüller, H., Varma, R., Arnott, W. P., Kuhns, H. D., Etyemezian, V., and Gillies, J. A.: Scattering cross-section emission factors for visibility and radiative transfer applications: Military vehicles traveling on unpaved roads, J. Air \& Waste Manage. Assoc., 55, 1743-1750, 2005.

Moosmüller, H., Engelbrecht, J. P., Skiba, M., Frey, G., Chakrabarty, R. K., and Arnott, W. P.: Single scattering albedo of fine mineral dust aerosols controlled by iron concentration, J. Geophys. Res., 117, D11210, https://doi.org/10.1029/2011JD016909, 2012.

Muhs, D. R., Prospero, J. M., Baddock, M. C., and Gill, T. E.: Identifying sources of aeolian mineral dust: Present and past, in: Mineral Dust, A Key Player in the Earth System, edited by: Knippertz, P. and Stuut, J.-B. W., Springer Science + Business Media Dordrecht, 51-74, 2014.

Nickovic, S., Vukovic, A., Vujadinovic, M., Djurdjevic, V., and Pejanovic, G.: Technical Note: High-resolution mineralogical database of dust-productive soils for atmospheric dust modeling, Atmos. Chem. Phys., 12, 845-855, https://doi.org/10.5194/acp12-845-2012, 2012.

Nihlen, T. and Lund, S. O.: Influence of aeolian dust on soil Formation in the Aegean area, Z. Geomorphol., 393, 341-361, 1995.

Notaro, M., Alkolibi, F., Fadda, E., and Bakhrjy, F.: Trajectory analysis of Saudi Arabian dust storms, J. Geophys. Res.-Atmos., 118, 6028-6043, https://doi.org/10.1002/jgrd.50346, 2013.

Notholt, A. J. G., Sheldon, R. P., and Davidson, D. F.: Phosphate deposits of the world, Volume 2, Phosphate rock resources, Cambridge University Press, New York, 600 pp., 2005.

Offer, Z. Y. and Goossens, D.: Ten years of aeolian dust dynamics in a desert region (Negev Desert, Israel): analysis of airborne dust concentration, dust accumulation and the high-magnitude dust events, J. Arid Environ., 47, 211-249, https://doi.org/10.1006/jare.2000.0706, 2001.

Osipov, S., Stenchikov, G., Brindley, H., and Banks, J.: Diurnal cycle of the dust instantaneous direct radiative forcing over the Arabian Peninsula, Atmos. Chem. Phys., 15, 9537-9553, https://doi.org/10.5194/acp-15-9537-2015, 2015.

Perlwitz, J. P., Pérez García-Pando, C., and Miller, R. L.: Predicting the mineral composition of dust aerosols - Part 1: Representing key processes, Atmos. Chem. Phys., 15, 11593-11627, https://doi.org/10.5194/acp-15-11593-2015, 2015a.

Perlwitz, J. P., Pérez García-Pando, C., and Miller, R. L.: Predicting the mineral composition of dust aerosols - Part 2: Model evaluation and identification of key processes with observations, Atmos. Chem. Phys., 15, 11629-11652, https://doi.org/10.5194/acp-15-11629-2015, 2015 b.

Prospero, J. M., Ginoux, P., Torres, O., Nicholson, S. E., and Gill, T. E.: Environmental characterization of global sources of atmospheric soil dust identified with the Nimbus 7 Total Ozone Mapping Spectrometer (TOMS) absorbing aerosol product, Rev. Geophys., 40, 2-1-2-31, https://doi.org/10.1029/2000RG000095, 2002.

Pye, K.: Aeolian dust and dust deposits, Academic Press, London, 1987.

Rao, A., Pillai, R., Mani, M., and Ramamurthy, P.: Influence of dust deposition on photovoltaic panel performance, Energy Procedia, 54, 690-700, https://doi.org/10.1016/j.egypro.2014.07.310, 2014.

Rietveld, H. M.: A profile refinement method for nuclear and magnetic structures, J. Appl. Crystallogr., 2, 65-71, dx.doi.org/10.1107/S0021889869006558, 1969.

Scanza, R. A., Mahowald, N., Ghan, S., Zender, C. S., Kok, J. F., Liu, X., Zhang, Y., and Albani, S.: Modeling dust as component minerals in the Community Atmosphere Model: development of framework and impact on radiative forcing, Atmos. Chem. Phys., 15, 537-561, https://doi.org/10.5194/acp-15-537-2015, 2015.

Scheuvens, D. and Kandler, K.: On composition, morphology, and size distribution of airborne mineral dust, in: Mineral Dust, a Key Player in the Earth System, edited by: Knippertz, P. and Stuut, J.-B. W., Springer Science + Business Media Dordrecht, 15-49, 2014.

Schulz, M., Prospero, J. M., Baker, A. R., Dentener, F., Ickes, L., Liss, P. S., Mahowald, N. M., Nickovic, S., García-Pando, C. P., Rodríguez, S., Sarin, M., Tegen, I., and Duce, R. A.: Atmospheric transport and deposition of mineral dust to the ocean: implications for research needs, Environ. Sci. Technol., 46, 1039010404, https://doi.org/10.1021/es300073u, 2012.

Smith, R. M. and Twiss, P. C.: Extensive gaging of dust deposition rates, Transactions of the Kansas Academy of Science, 68, 310321, 1965.

Sokolik, I. N. and Toon, O. B.: Incorporation of mineralogical composition into models of the radiative properties of mineral aerosol from UV to IR wavelengths, J. Geophys. Res.-Atmos., 104, 9423-9444, https://doi.org/10.1029/1998JD200048, 1999.

Sow, M., Goossens, D., and Rajot, J. L.: Calibration of the MDCO dust collector and of four versions of the inverted frisbee dust deposition sampler, Geomorphology, 82, 360-375, https://doi.org/10.1016/j.geomorph.2006.05.013, 2006.

Sturges, W. T., Harrison, R. M., and Barrie, L. A.: Semi-quantitative $\mathrm{X}$-ray diffraction analysis of size fractionated atmospheric particles, Atmos. Environ., 23, 1083-1098, 1989.

Sulaiman, S. A., Singh, A. K., Mokhtar, M. M. M., and Bou-Rabee, M. A.: Influence of dirt accumulation on 
performance of PV panels, Energy Procedia, 50, 50-56, https://doi.org/10.1016/j.egypro.2014.06.006, 2014.

Tanaka, T. Y. and Chiba, M.: A numerical study of the contributions of dust source regions to the global dust budget, Global Planet. Change, 52, 88-104, https://doi.org/10.1016/j.gloplacha.2006.02.002, 2006.

Twomey, S. A., Piepgrass, M., and Wolfe, T. L.: An assessment of the impact of pollution on global cloud albedo, Tellus B, 36, 356366, https://doi.org/10.1111/j.1600-0889.1984.tb00254.x, 1984.

US EPA: Compendium of Methods for the Determination of Inorganic Compounds in Ambient Air, Compendium Method IO-3.3, Determination of metals in ambient particulate matter using $\mathrm{X}$ ray fluorescence (XRF) spectroscopy, EPA/625/R-96/010, 3.3-13.3-32, US EPA, Washington, DC, 1999.

Vallack, H. W.: A field evaluation of Frisbee-type dust deposit gauges, Atmos. Environ., 29, 1465-1469, https://doi.org/10.1016/1352-2310(95)00079-E, 1995.

Vallack, H. W. and Chadwick, M. J.: A field comparison of dust deposit gauge performance at two sites in Yorkshire, Atmos. Environ. A, 26, 1445-1451, https://doi.org/10.1016/09601686(92)90129-9, 1992.

Vallack, H. W. and Chadwick, M. J.: Monitoring airborne dust in a high density coal-fired power station region in North Yorkshire, Environ. Pollut., 80, 177-183, https://doi.org/10.1016/02697491(93)90145-E, 1993.
Vallack, H. W. and Shillito, D. E.: Suggested guidelines for deposited ambient dust, Atmos. Environ., 32, 2737-2744, https://doi.org/10.1016/S1352-2310(98)00037-5, 1998.

Wang, W., Huang, J., Minnis, P., Hu, Y., Li, J., Huang, Z., Ayers, J. K., and Wang, T.: Dusty cloud properties and radiative forcing over dust source and downwind regions derived from A-Train data during the Pacific Dust Experiment, J. Geophys. Res., 115, D00H35, https://doi.org/10.1029/2010JD014109, 2010.

Washington, R. and Todd, M. C.: Atmospheric controls on mineral dust emission from the Bodélé depression, Chad: The role of the low level jet, Geophys. Res. Lett., 32, L17701, https://doi.org/10.1029/2005GL023597, 2005.

Weese, C. B. and Abraham, J. H.: Potential health implications associated with particulate matter exposure in deployed settings in southwest Asia, Inhal. Toxicol., 21, 291-296, https://doi.org/10.1080/08958370802672891, 2009.

Yu, Y., Notaro, M., Liu, Z., Kalashnikova, O., Alkolibi, F., Fadda, E., and Bakhrjy, F.: Assessing temporal and spatial variations in atmospheric dustover Saudi Arabia through satellite, radiometric, and station data, J. Geophys. Res.-Earth J. Geophys. Res.-Atmos., 118, 13253-13264, https://doi.org/10.1002/2013JD020677, 2013. 